OPEN ACCESS

Edited by:

Daniela De Biase,

Sapienza University of Rome, Italy

Reviewed by:

Nicolai Kallscheuer,

Radboud University Nijmegen,

Netherlands

Fernando Pérez-García,

Norwegian University of Science

and Technology, Norway

Koichi Toyoda,

Research Institute of Innovative

Technology for the Earth, Japan

${ }^{*}$ Correspondence:

Meike Baumgart

m.baumgart@fz-juelich.de

Michael Bott

m.bott@fz-juelich.de

†Present address:

Lingfeng Zhu,

Center for Synthetic Biochemistry,

Institute of Synthetic Biology,

Shenzhen Institutes of Advanced

Technologies, Chinese Academy

of Sciences, Shenzhen, China

Specialty section:

This article was submitted to Microbial Physiology and Metabolism,

a section of the journal

Frontiers in Microbiology

Received: 19 March 2020 Accepted: 17 September 2020

Published: 27 October 2020

Citation:

Zhu L, Mack C, Wirtz A, Kranz A,

Polen T, Baumgart $M$ and Bott $M$ (2020) Regulation of $\gamma$-Aminobutyrate (GABA) Utilization in Corynebacterium glutamicum by the PucR-Type

Transcriptional Regulator GabR and by Alternative Nitrogen

and Carbon Sources.

Front. Microbiol. 11:544045. doi: 10.3389/fmicb.2020.544045

\section{Regulation of $\gamma$-Aminobutyrate} (GABA) Utilization in Corynebacterium glutamicum by the PucR-Type Transcriptional Regulator GabR and by Alternative Nitrogen and Carbon Sources

\author{
Lingfeng Zhut, Christina Mack, Astrid Wirtz, Angela Kranz, Tino Polen, Meike Baumgart* \\ and Michael Bott*
}

IBG-1: Biotechnology, Institute of Bio- and Geosciences, Forschungszentrum Jülich, Jülich, Germany

$\gamma$-Aminobutyric acid (GABA) is a non-proteinogenic amino acid mainly formed by decarboxylation of L-glutamate and is widespread in nature from microorganisms to plants and animals. In this study, we analyzed the regulation of GABA utilization by the Gram-positive soil bacterium Corynebacterium glutamicum, which serves as model organism of the phylum Actinobacteria. We show that GABA usage is subject to both specific and global regulatory mechanisms. Transcriptomics revealed that the gabTDP genes encoding GABA transaminase, succinate semialdehyde dehydrogenase, and GABA permease, respectively, were highly induced in GABA-grown cells compared to glucose-grown cells. Expression of the gabTDP genes was dependent on GABA and the PucR-type transcriptional regulator GabR, which is encoded divergently to gabT. A $\triangle$ gabR mutant failed to grow with GABA, but not with glucose. Growth of the mutant on GABA was restored by plasmid-based expression of gabR or of gabTDP, indicating that no further genes are specifically required for GABA utilization. Purified GabR (calculated mass $55.75 \mathrm{kDa}$ ) formed an octamer with an apparent mass of $420 \mathrm{kDa}$ and bound to two inverted repeats in the gabR-gabT intergenic region. Glucose, gluconate, and myo-inositol caused reduced expression of gabTDP, presumably via the cAMPdependent global regulator GlxR, for which a binding site is present downstream of the gabT transcriptional start site. C. glutamicum was able to grow with GABA as sole carbon and nitrogen source. Ammonium and, to a lesser extent, urea inhibited growth on GABA, whereas L-glutamine stimulated it. Possible mechanisms for these effects are discussed.

Keywords: Corynebacterium glutamicum, Actinobacteria, $\gamma$-aminobutyrate, PucR-type regulator GabR, cAMPdependent regulator GIxR, nitrogen metabolism, carbon metabolism 


\section{INTRODUCTION}

$\gamma$-Aminobutyric acid (GABA) is a non-proteinogenic amino acid, which is widespread in nature from microorganisms to plants and animals. GABA is formed by many gram-negative and gram-positive bacteria as part of the acid stress response (Cotter and Hill, 2003; Foster, 2004; Krulwich et al., 2011; De Biase and Pennacchietti, 2012). The irreversible decarboxylation of L-glutamate by glutamate decarboxylase results in the formation of GABA and carbon dioxide and consumes a proton within the cytoplasm, thereby acting against acid stress. An antiporter takes up L-glutamate and exports GABA. This acid stress response can also start from L-glutamine, which is first converted to L-glutamate and ammonia by a glutaminase (Pennacchietti et al., 2018). The human gut microbiome contains several GABA-producing or GABA-consuming species, and there might be a connection between GABA production in the gut and depressive disorders (Strandwitz et al., 2019). In plants, GABA plays a role in stress responses and at the interface of carbon and nitrogen metabolism (Michaeli and Fromm, 2015). In the brain of mammals, GABA is an important neurotransmitter (Abdou et al., 2006; Ben-Ari et al., 2007). GABA has also gained much attention as a building block for the synthesis of 2-pyrrolidone and the biodegradable polyamide nylon 4 (Kawasaki et al., 2005). Therefore, microbial synthesis of GABA has frequently been studied (Krulwich et al., 2011; Dhakal et al., 2012; Jorge et al., 2016; Xu et al., 2017).

Due to its widespread occurrence in nature, GABA can be used by many bacteria as carbon and nitrogen source. After uptake by specific transporters (usually named GabP), a transaminase (GabT) converts GABA and 2-oxoglutarate in a pyridoxal 5-phosphate (PLP)-dependent reaction to succinate semialdehyde and glutamate. Succinate semialdehyde is then oxidized by an $\mathrm{NAD}(\mathrm{P})^{+}$-dependent succinate semialdehyde dehydrogenase (GabD) to succinate, an intermediate of the central metabolism (Scott and Jakoby, 1958; Dover and Halpern, 1972; Feehily and Karatzas, 2013). Despite the fact that many bacteria possess the characteristic genes involved in GABA metabolism, their regulation has so far only been studied in a few species such as Bacillus subtilis, Bacillus thuringiensis, or Escherichia coli. The best-studied regulator is probably GabR of B. subtilis (designated here $\mathrm{GabR}_{\mathrm{Bs}}$ ), which belongs to the MocR/GabR subfamily of the GntR family of transcriptional regulators (Edayathumangalam et al., 2013; $\mathrm{Wu}$ et al., 2017). GabR $\mathrm{Bs}_{\mathrm{Bs}}$ consists of an N-terminal helixturn-helix (HTH) domain and a C-terminal aminotransferase domain and activates its target genes gabTD in the presence of GABA and PLP (Belitsky, 2004). Surprisingly, in the close relative $B$. thuringiensis, the regulation of GABA metabolism is different. Here, the regulator $\mathrm{GabR}_{\mathrm{Bt}}$ belongs to the family of bacterial enhancer binding proteins that function as activators of $\sigma^{54}$-dependent promoters. GabR $R_{B t}$ is composed of a PerARNT-Sim (PAS) domain, a $\sigma^{54}$ interaction domain, and a C-terminal HTH domain and activates its target gene gabT in the presence of GABA and succinate semialdehyde (Zhu et al., 2010; Peng et al., 2014). In E. coli, the genes gabTDP are presumably organized in an operon gabTDPC together with $g a b C$, and activated under nitrogen limitation by the Nac regulator (Schneider et al., 2002). The product of gabC is a transcriptional regulator belonging to the FadR subfamily of the GntR family of transcriptional regulators and seems to repress this operon. However, the exact physiological function of $\mathrm{GabC}_{\mathrm{Ec}}$ is unclear up to now (Schneider et al., 2002). GABA is also an intermediate of putrescine degradation to succinate in E. coli, which involves PuuE as isoenzyme of GabT and PuuC as isoenzyme of GabD (Kurihara et al., 2010; Schneider and Reitzer, 2012). In summary, the regulation of genes involved in GABA metabolism appears to be rather diverse in bacteria.

Corynebacterium glutamicum is a gram-positive soil bacterium widely used for the industrial production of amino acids, in particular the flavor enhancer L-glutamate and the feed additive L-lysine (Eggeling and Bott, 2005). The wild type is unable to synthesize GABA, but recombinant strains for GABA production were constructed (Shi and Li, 2011; Takahashi et al., 2012; Shi et al., 2013; Jorge et al., 2016). In the course of these studies, it became clear that C. glutamicum is able to degrade GABA and a number of proteins involved in this process were studied (Figure 1). GabP ( $\mathrm{Cg} 0568)$ is a secondary $\mathrm{Na}^{+}$-dependent transporter for GABA uptake with a $K_{m}$ value of $34.2 \pm 1.1 \mu \mathrm{M}$ and a $V_{\max }$ of $67.3 \pm 1.0 \mathrm{nmol} \mathrm{min}{ }^{-1}(\mathrm{mg}$ cell dry weight $)^{-1}$ at $\mathrm{pH} 7.5$ and essential for GABA utilization (Zhao et al., 2012). GabT (Cg0566) is a GABA transaminase and the purified enzyme has a specific activity of $1.34 \mathrm{U} / \mathrm{mg}$ protein and $K_{m}$ values of $10.65 \mathrm{mM}$ for GABA and $9.21 \mathrm{mM}$ for 2-oxoglutarate (Shi et al., 2017). GabT was shown to be a tetramer and the crystal structure in complex with PLP-GABA allowed the identification of the key residues that contribute to the formation of the active site (Hong and Kim, 2019). Since a $g a b T$ deletion strain was still able to degrade GABA, the presence of another transaminase catalyzing this reaction was suggested ( $\mathrm{Ni}$ et al., 2015). The protein encoded by bioA (cg2885) was recently reported to possess GABA transaminase activity, but the specific activity of the purified BioA enzyme was only $2 \%$ of the GabT activity (Shi et al., 2017). With respect to succinate semialdehyde dehydrogenase, three genes were annotated to encode this enzyme, namely $g a b D$ (cg0566), cg0067, and cg3004 (Figure 1) (Kalinowski et al., 2003). None of the corresponding proteins has been biochemically characterized to our knowledge.

In this study, our aim was to investigate the regulation of GABA utilization in C. glutamicum. We show that the gabTDP operon is regulated by a specific transcriptional regulator, GabR, which does not belong to the regulator families described above for GabR proteins of other bacteria, but to the PucR family, further confirming the heterogeneity in transcriptional regulation of the genes involved in GABA transport and metabolism. GabR presumably requires GABA for transcriptional activation, but not for DNA-binding. The gabTDP operon is probably also regulated by the cAMP-dependent global regulator GlxR, which is proposed to repress expression when alternative carbon sources are present. Besides alternative carbon sources, also alternative nitrogen sources have a profound 


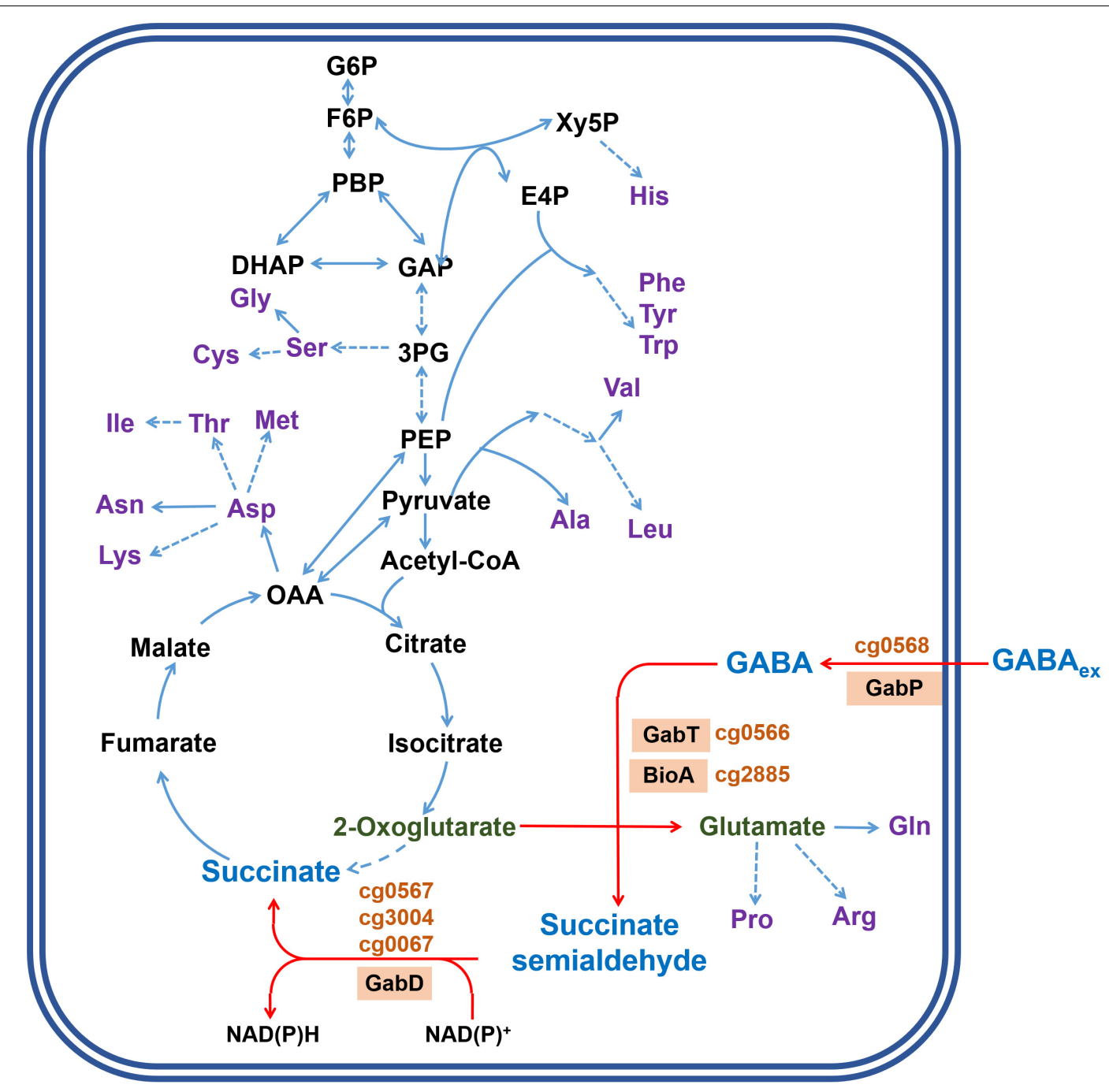

FIGURE 1 | Model of GABA metabolism in C. glutamicum and integration into central metabolism. The metabolites and reactions specifically involved in GABA metabolism are indicated by blue letters and red arrows, respectively. The proteins involved in GABA transport and degradation and the corresponding locus tags are indicated in orange. GabP is a sodium ion-coupled secondary transporter for GABA uptake (Zhao et al., 2012). GabT functions as $\gamma$-aminobutyrate aminotransferase (Shi et al., 2017). BioA (cg2885) was reported to also possess some GABA aminotransferase activity (Shi et al., 2017). GabD (cg0567) as well as two further proteins encoded by cg0067 and cg3004 are annotated as succinate semialdehyde dehydrogenases (Kalinowski et al., 2003). GABA ex represents extracellular GABA. Metabolites involved in central metabolism are shown in black letters, amino acids in purple letters. Solid blue arrows indicate conversions catalyzed by a single enzyme, dashed lines represents conversions composed of several enzymatic steps. Abbreviations: DHAP, dihydroxyacetone phosphate; E4P, erythrose 4-phosphate; F6P, fructose 6-phosphate; FBP, fructose 1,6-bisphosphate; GAP, glyceraldehyde 3-phosphate; G6P, glucose 6-phosphate; OAA, oxaloacetate; PEP, phosphoenolpyruvate; 3PG, 3-phosphoglycerate; Xy5P, xylulose 5-phosphate.

influence on GABA utilization, with ammonium and urea acting as inhibitors and glutamine serving as stimulator.

\section{MATERIALS AND METHODS}

\section{Bacterial Strains, Plasmids and Growth Conditions}

The bacterial strains and plasmids used in this study are listed in Table 1. The C. glutamicum ATCC 13032 type strain served as wild type (WT). C. glutamicum was routinely cultivated at $30^{\circ} \mathrm{C}$. For precultivation of C. glutamicum, brain heart infusion (BHI) medium (Becton Dickinson GmbH, Heidelberg, Germany) with $90 \mathrm{~g} \mathrm{~L}^{-1}$ sorbitol was used. The cells of these precultures were harvested by centrifugation $\left(5,000 \mathrm{~g}, 4^{\circ} \mathrm{C}\right.$, $10 \mathrm{~min}$ ), and washed twice with phosphate buffer (100 $\mathrm{mM}$ $\mathrm{KH}_{2} \mathrm{PO}_{4} / \mathrm{Na}_{2} \mathrm{HPO}_{4} \mathrm{pH}$ 7.0). Growth experiments were routinely performed in a BioLector microcultivation system (m2p-labs, Baesweiler, Germany) using 48-well FlowerPlates (m2p-labs) containing $750 \mu \mathrm{L}$ CGXII minimal medium (Keilhauer et al., 1993) supplemented with $30 \mathrm{mg} \mathrm{L}^{-1}$ protocatechuic acid as iron chelator. In the BioLector, growth of the cells is measured as scattered light at $620 \mathrm{~nm}$ (Kensy et al., 2009a,b). Please note that the absolute backscatter values of the graphs in this manuscript 
TABLE 1 | Bacterial strains and plasmids used in this study.

\begin{tabular}{|c|c|c|}
\hline Strain or plasmid & Relevant characteristics & Source or references \\
\hline \multicolumn{3}{|l|}{ E. coli } \\
\hline $\mathrm{DH} 5 \alpha$ & $\begin{array}{l}\mathrm{F}^{-} \text {(80dlac } \Delta\left(\text { lacZ)M15 } \Delta\left(\text { lacZYA-argF) U169 endA1 recA1 hsdR17 }\left(\mathrm{r}_{\mathrm{K}}{ }^{-}, \mathrm{m}_{\mathrm{K}}{ }^{+}\right)\right.\right. \\
\text {deoR thi-1 phoA supE44 } \lambda^{-} \text {gyrA96 relA1; strain used for cloning procedures }\end{array}$ & (Hanahan, 1983) \\
\hline BL21(DE3) & F- ompT hsd $S_{\mathrm{B}}\left(\mathrm{r}_{\mathrm{B}^{-}}, \mathrm{m}_{\mathrm{B}^{-}}\right) \mathrm{gal} \mathrm{dcm}(\mathrm{DE} 3) ;$ host for protein production & (Studier and Moffatt, 1986) \\
\hline \multicolumn{3}{|l|}{ C. glutamicum } \\
\hline ATCC $13032(\mathrm{Cg}$ WT) & Biotin-auxotrophic wild type & (Kinoshita et al., 1957) \\
\hline$\Delta g a b R$ & WT derivative with an in-frame deletion of gabR (cg0565) & This work \\
\hline$\Delta g d h(\mathrm{LN} \Delta \mathrm{GDH})$ & ATCC 13032 with deletion of gdh (cg2280) & (Müller et al., 2006) \\
\hline$\Delta g \ln A(\mathrm{LN} \Delta \mathrm{GS})$ & ATCC 13032 with deletion of $g \ln A$ (cg2429) & (Müller et al., 2006) \\
\hline$\Delta g l t B D(L N \Delta g l t B D)$ & ATCC 13032 with deletion of gltB (cg0229) and gltD (cg0230) & (Rehm et al., 2010) \\
\hline$\Delta g \ln A \Delta g \ln A 2 \Delta g d h(\mathrm{DA}-2)$ & ATCC 13032 with deletion of gdh (cg2280), glnA (cg2429) and glnA2 (cg2477) & (Walter et al., 2008) \\
\hline \multicolumn{3}{|l|}{ Plasmids } \\
\hline pK19mobsacB & $\begin{array}{l}\mathrm{Kan}^{\mathrm{R}} \text {; plasmid for allelic exchange in C. glutamicum; (pK18 ori } \mathrm{V}_{E . c .}, \text { sacB, } \\
\operatorname{lac} Z \alpha)\end{array}$ & (Schäfer et al., 1994) \\
\hline pK19mobsacB- $\Delta$ gabR & $\begin{array}{l}\mathrm{Kan}^{\mathrm{R}} \text {.; pK19mobsacB derivative containing a PCR product covering the up- } \\
\text { and downstream regions of gabR (cg0565) }\end{array}$ & This work \\
\hline pAN6 & $\begin{array}{l}\mathrm{Kan}^{\mathrm{R}} \text {; C. glutamicum/E. coli shuttle vector for regulated gene expression using } \\
\text { the Ptac promoter, derivative of pEKEx2. }\end{array}$ & (Frunzke et al., 2008) \\
\hline pAN6-gabR & $\mathrm{Kan}^{\mathrm{R}}$; pAN6 derivative for expression of gabR (cg0565) under control of $\mathrm{P}_{\text {tac }}$ & This work \\
\hline pAN6-gabTDP & $\mathrm{Kan}^{\mathrm{R}}$; pAN6 derivative for expression of gabTDP cluster & This work \\
\hline pET-TEV & $\begin{array}{l}\text { Kan }^{\mathrm{R}} \text {; pET28b derivative for overexpression of genes in } E \text {. coli, adding an } \\
\text { N-terminal decahistdine tag and a TEV protease cleavage site to the target } \\
\text { protein (pBR322 oriV } E_{E . c .}, \mathrm{P}_{\mathrm{T} 7}, \text { lacl) }\end{array}$ & (Bussmann et al., 2010) \\
\hline pET-TEV-gabR & $\mathrm{Kan}^{\mathrm{R}}$; pET-TEV derivative for overproduction of GabR (cg0565) & This work \\
\hline pJC1-Ptac-eyfp & $\mathrm{Kan}^{\mathrm{R}}$; pJC1 derivative containing the eyfp gene under the control of $\mathrm{P}_{\text {tac }}$ & (Kortmann et al., 2015) \\
\hline pJC1-venus-term & $\begin{array}{l}\text { Kan }{ }^{R} \text {; E. coli-C. glutamicum shuttle vector, pJC1 derivative carrying the venus } \\
\text { coding sequence and additional terminators }\end{array}$ & (Baumgart et al., 2013) \\
\hline pJC1-P gabT-eYFP & $\begin{array}{l}\text { Kan }{ }^{R} ; \text { pJC1-venus-term derivative carrying the promoter of gabT (cg0566) } \\
\text { fused to eyfp }\end{array}$ & This work \\
\hline pJM0462 & $\begin{array}{l}\mathrm{Cm}^{\mathrm{R}} ; \mathrm{pASK}-\mathrm{IBA}-3 \mathrm{C} \text { derivative with the coding sequence of gabT (cg0566, } \\
\text { NCgl0462) }\end{array}$ & (Marienhagen et al., 2005) \\
\hline
\end{tabular}

differ because of the use of different instruments. Due to this, reference cultures were always included to allow comparison between different experiments. For determination of GABA and glucose consumption, cells were cultured in 500-mL baffled shake flasks with $50 \mathrm{~mL}$ medium that were incubated at $30^{\circ} \mathrm{C}$ and $130 \mathrm{rpm}$. E. coli was grown at $37^{\circ} \mathrm{C}$ in lysogeny broth (Bertani, 1951). When required for plasmid maintenance, media were supplemented with kanamycin $\left(50 \mu \mathrm{g} \mathrm{mL}{ }^{-1}\right.$ for E. coli, $25 \mu \mathrm{g}$ $\mathrm{mL}^{-1}$ for C. glutamicum) or chloramphenicol $\left(20 \mu \mathrm{g} \mathrm{mL}^{-1}\right)$.

\section{Recombinant DNA Work and Construction of Deletion Mutants}

Routine methods such as PCR, DNA restriction and ligation were performed using standard protocols (Sambrook et al., 1989; van der Rest et al., 1999). All oligonucleotides used in this study are listed in Supplementary Table 1 and were synthesized by Eurofins Genomics (Ebersberg, Germany). The enzymes for recombinant DNA work were obtained from New England Biolabs (Frankfurt, Germany) and Thermo Fisher Scientific (Vilnius, Lithuania). The correctness of the insert sequences of all recombinant plasmids was verified by DNA sequencing (Eurofins Genomics, Ebersberg, Germany).
The C. glutamicum $\triangle g a b R$ strain was constructed by allelic exchange using the plasmid pK19mobsacB (Schäfer et al., 1994) as described before (Niebisch and Bott, 2001). For construction of pK19mobsacB- $\Delta g a b R$, the oligonucleotide pairs cg0565frontF/R and $c g 0565 \mathrm{backF} / \mathrm{R}$ were used to amplify DNA regions of approximately 500 bp upstream and downstream of gabR using C. glutamicum WT genomic DNA as template. The resulting PCR products were fused by Gibson assembly (Gibson et al., 2009) with pK19mobsacB which had been digested with BamHI and PstI. After successful construction, pK19mobsacB- $\Delta g a b R$ was used to transform competent $C$. glutamicum WT. The transformed cells were first selected for kanamycin resistance and subsequently for tolerance toward sucrose. Successful deletion of gabR was confirmed by colony PCR with the oligonucleotides cg0565checkF and cg0565checkR, which anneal outside of the deleted regions. Out of six analyzed clones, three showed the desired $g a b R$ deletion, while three clones represented the WT situation.

For construction of plasmid pAN6-gabR, the gabR coding region was amplified by PCR using the oligonucleotides $0565 \mathrm{~F}$ and $0565 \mathrm{R}$ and chromosomal DNA of C. glutamicum WT as template. After digestion with NdeI and NheI, the PCR product was cloned into the expression plasmid pAN6 cut with 
the same restriction enzymes using the Rapid DNA Ligation Kit (Roche Diagnostics, Mannheim, Germany). The plasmid pET-TEV-gabR was constructed similar to pAN6-gabR. The $g a b R$ gene was amplified with the oligonucleotides $0565 \mathrm{~F}$ and petfhis0565R, the PCR product was digested with NdeI and HindIII and ligated with pET-TEV cut with the same restriction enzymes. For construction of plasmid pAN6-gabTDP, the genes gabTDP, were amplified by PCR using the oligonucleotide pair gabtdpF/gabtdpR and chromosomal DNA of C. glutamicum WT as template. The resulting PCR product was fused with pAN6 cut with NdeI and NheI by Gibson assembly.

For construction of plasmid pJC1- $\mathrm{P}_{g a b T}-\mathrm{eYFP}$, a 500-bp fragment covering the gabTDP promoter region immediately upstream of the gabT start codon was amplified using the oligonucleotide pair PgabTF/PgabTR with genomic DNA of C. glutamicum WT as template. The eYFP-encoding gene was amplified with the oligonucleotide pair eYFPF/eYFP-termR and plasmid DNA of pJC1-P tac -eyfp as template. The two PCR fragments were fused by Gibson assembly with pJC1-venus-term, which had been digested with BamHI and SpeI.

\section{DNA Microarray Analysis}

Comparative transcriptome analysis using DNA microarrays was performed as described previously (Vogt et al., 2014), except that $\left(\mathrm{NH}_{4}\right)_{2} \mathrm{SO}_{4}$ was omitted from the medium to exclude ammonium and $20 \mathrm{mM} \mathrm{K}_{2} \mathrm{SO}_{4}$ was added to avoid a possible sulfate limitation. The medium still contains $83 \mathrm{mM}$ urea as nitrogen source. C. glutamicum WT was cultivated in this modified medium with either $62.5 \mathrm{mM}$ GABA or with $41.7 \mathrm{mM}$ glucose as carbon source, corresponding to $250 \mathrm{mM}$ C. When an optical density at $600 \mathrm{~nm}\left(\mathrm{OD}_{600}\right)$ of 5 was reached [measured with an Ultrospec 2100pro spectrophotometer (Biochrom, Berlin, Germany)], the cells were harvested by centrifugation $\left(4000 g, 10 \mathrm{~min}, 4^{\circ} \mathrm{C}\right)$. The cell pellet was subsequently frozen in liquid nitrogen and stored at $-80^{\circ} \mathrm{C}$. Total RNA isolation of C. glutamicum cells was performed using the RNeasy Mini kit (Qiagen, Hilden, Germany), and the RNA was kept at $-80^{\circ} \mathrm{C}$ until further use. Fluorescently labeled cDNA copies of total RNA of C. glutamicum were prepared using SuperScript III reverse transcriptase (Life Technologies, Darmstadt, Germany). To remove unincorporated fluorophores, the probes were purified using Amicon Centrifugal Filters (Merck Millipore, Darmstadt, Germany). The cDNA probes labeled with Cy3 and Cy5 were hybridized using Agilent's Gene Expression Hybridization Kit (Waldbronn, Germany), hybridization oven and hybridization chamber. After $16 \mathrm{~h}$ of hybridization at $65^{\circ} \mathrm{C}$, the microarrays were washed using Agilent's Wash Buffer Kit according to the manufacturer's instructions. Signal acquisition was performed with a GenePix 4000B laser scanner and GenePix Pro 7.0 software (Molecular Devices, Sunnyvale, CA, United States). For background correction of spot intensities, ratio calculation and ratio normalization, data were processed using the BioConductor R-packages limma and marray ${ }^{1}$. The full microarray data sets of this study have been deposited in the NCBI Gene

${ }^{1}$ http://www.bioconductor.org
Expression Omnibus and can be found under the GEO accession number GSE138829.

\section{Determination of the Transcriptional Start Sites (TSSs)}

The TSS of gabT was initially determined using the $5^{\prime} / 3^{\prime}$ RACE Kit (Roche Diagnostics, Mannheim, Germany). In brief, RNA was extracted from C. glutamicum WT cells cultivated with GABA as sole carbon and nitrogen source using an RNeasy Mini Kit (Qiagen). Then transcription of specific mRNA sequences into first-strand cDNA was performed using the extracted RNA and oligonucleotide GABTTS1R (Supplementary Table 1). A homopolymeric A-tail was added to the $3^{\prime}$-end of the firststrand cDNA using recombinant terminal transferase and AATP. Finally, the amplification of dA-tailed cDNA was performed using first and second round PCR using the primers GABTTS2R and GABTTS3R, respectively (Supplementary Table 1). The PCR products were sequenced to determine the TSS. The TSS determination was performed independently for three biological replicates.

In an alternative approach, the TSSs present within the gabRgabTDP region were analyzed by RNAseq using RNA of WT cells cultivated with GABA as sole carbon and energy source. Three independent cultures $(5 \mathrm{ml} \mathrm{BHI})$ were inoculated with a single colony from a fresh agar plate and cultivated at $30^{\circ} \mathrm{C}$ and $170 \mathrm{rpm}$ during the day. The cells were washed two times with $0.9 \%(\mathrm{w} / \mathrm{v}) \mathrm{NaCl}$ and used to inoculate the second precultures of $20 \mathrm{ml}$ CGXII medium with $2 \%(\mathrm{w} / \mathrm{v})$ glucose in a 1:100 dilution. These cultures were cultivated at $30^{\circ} \mathrm{C}$ and $130 \mathrm{rpm}$ overnight. For the main cultures, $50 \mathrm{ml}$ CGXII medium without ammonium and urea but with $62.5 \mathrm{mM}$ GABA as carbon and nitrogen source were inoculated with the precultures to an $\mathrm{OD}_{600}$ of 1 . The main cultures were incubated at $30^{\circ} \mathrm{C}$ and $130 \mathrm{rpm}$ and harvested after $6 \mathrm{~h}$ at an $\mathrm{OD}_{600}$ of 2.52.7. RNA isolation was performed with the RNeasy Mini Kit (Qiagen, Hilden, Germany). For the sequencing, RNA of all three cultures was mixed in equal amounts. Further RNA processing and sequencing was performed by Vertis Biotechnologie AG (Freising-Weihenstephan, Germany). Processing and mapping of the 10,117,524 single-end sequenced reads was performed with the CLC Genomics Workbench (Qiagen Aarhus A/S). Reads were trimmed by removing adapter sequences using the Trim Sequences tool and filtered for Phred quality scores $<30$ (Ewing and Green, 1998). Trimmed reads (10,052,707) were mapped to the C. glutamicum reference sequence (BX927147). Automatic detection of TSSs was done with ReadXplorer (Hilker et al., 2014) using the following parameters: (i) Only single perfect mappings without errors were considered. (ii) Minimum percentage of coverage increase was set to $100 \%$ and minimum number of reads starts to 20 . Every possible TSS for cg0565-cg0568 was manually checked including TSS with less than 20 reads.

\section{Protein Production and Purification}

For GabR production and purification, E. coli BL21(DE3) harboring pET-TEV-gabR was first cultivated in $5 \mathrm{~mL}$ LB medium 
with $50 \mu \mathrm{g} \mathrm{mL}{ }^{-1}$ kanamycin in $20 \mathrm{~mL}$ glass tubes at $37^{\circ} \mathrm{C}$ with shaking overnight. Subsequently, $2 \mathrm{~mL}$ preculture was used to inoculate $200 \mathrm{~mL} \mathrm{LB}$ medium with kanamycin in a $500 \mathrm{~mL}$ shake flask, which was cultivated at $37^{\circ} \mathrm{C}$ and $120 \mathrm{rpm}$. When the culture reached an $\mathrm{OD}_{600}$ of $0.6,0.2 \mathrm{mM}$ isopropyl $\beta$ D-1-thiogalactopyranoside (IPTG) was added to induce $g a b R$ expression. After induction, the cells were further cultivated at $16^{\circ} \mathrm{C}$ for $8 \mathrm{~h}$ and harvested by centrifugation $(4,000 \mathrm{~g}, 10 \mathrm{~min}$, $\left.4^{\circ} \mathrm{C}\right)$. The harvested cells were suspended in binding buffer (20 mM Tris- $\mathrm{HCl}, 500 \mathrm{mM} \mathrm{NaCl}, 1 \mathrm{mM}$ DTT, $10 \mathrm{mM}$ imidazole, $\mathrm{pH} 7.8$ ) and disrupted by sonication for 20 minutes while cooling on ice with a UP $200 \mathrm{~S}$ ultrasonic device (Hielscher, Germany) using a power amplitude of $55 \%$ and a pulse cycle of 0.3 . The resulting cell extract was centrifuged at $12,000 \mathrm{~g}$ for $20 \mathrm{~min}$ to remove cell debris and the supernatant was subjected to $\mathrm{Ni}^{2+}$ affinity chromatography using Ni-NTA Superflow (Qiagen, Hilden, Germany). The column was equilibrated with binding buffer. After adding the cell-free extract, the column was washed first with three column volumes of binding buffer and then with three column volumes of wash buffer $(20 \mathrm{mM}$ Tris- $\mathrm{HCl}, 500 \mathrm{mM}$ $\mathrm{NaCl}, 1 \mathrm{mM}$ DTT, $80 \mathrm{mM}$ imidazole, $\mathrm{pH}$ 7.8). GabR protein with an $\mathrm{N}$-terminal decahistidine tag was eluted with elution buffer (20 mM Tris- $\mathrm{HCl}, 500 \mathrm{mM} \mathrm{NaCl}, 1 \mathrm{mM}$ DTT, and $300 \mathrm{mM}$ imidazole, pH 7.8). Subsequently, the His-tag was cleaved off with tobacco etch virus (TEV) protease (Kapust and Waugh, 1999) by incubation of $12 \mathrm{mg}$ His-tagged GabR with $0.24 \mathrm{mg}$ Histagged TEV protease overnight at $4^{\circ} \mathrm{C}$ in TEV buffer $(25 \mathrm{mM}$ Tris-HCl, pH 8.0, 0.25 mM EDTA, 1 mM DTT). Subsequently, GabR was further purified by gel filtration with a Superdex ${ }^{\mathrm{TM}} 200$ increase 10/300 GL column (GE Healthcare, Freiburg, Germany) connected to an $\ddot{\mathrm{kta}}{ }^{\mathrm{TM}}$ Pure25 system (GE Healthcare) using $100 \mathrm{mM}$ phosphate buffer $\mathrm{pH} 7.0$ with $1 \mathrm{mM}$ DTT and a flow rate of $0.75 \mathrm{~mL} \mathrm{~min}-1$. The elution volumes of the standard proteins were $9.41 \mathrm{~mL}$ for thyroglobulin $(669 \mathrm{kDa}), 10.87 \mathrm{~mL}$ for apoferritin (443 kDa), $12.06 \mathrm{~mL}$ for amylase $(200 \mathrm{kDa}), 12.85 \mathrm{~mL}$ for alcohol dehydrogenase $(150 \mathrm{kDa}), 14.27 \mathrm{ml}$ for BSA $(66 \mathrm{kDa})$, $16.26 \mathrm{~mL}$ for carbonic anhydrase $(29 \mathrm{kDa})$, and $17.34 \mathrm{~mL}$ for cytochrome $c(12.4 \mathrm{kDa})$.

Overproduction and purification of the transaminase GabT were performed according to a previous publication (Marienhagen et al., 2005). E. coli BL21(DE3) carrying plasmid pJM0462 was precultivated in $5 \mathrm{~mL}$ LB medium with $20 \mu \mathrm{g}$ $\mathrm{mL}^{-1}$ chloramphenicol in $20 \mathrm{~mL}$ tubes at $37^{\circ} \mathrm{C}$ and $120 \mathrm{rpm}$ overnight. Subsequently, $2 \mathrm{~mL}$ preculture was used to inoculate $200 \mathrm{~mL}$ LB medium with $20 \mu \mathrm{g} \mathrm{mL}^{-1}$ chloramphenicol in a $500 \mathrm{~mL}$ shake flask, which was incubated at $37^{\circ} \mathrm{C}$ and $120 \mathrm{rpm}$. Induction of target gene expression was triggered by addition of $20 \mu \mathrm{L}$ anhydrotetracycline $\left(2 \mathrm{mg}\left(\mathrm{mL}\right.\right.$ ethanol) $\left.{ }^{-1}\right)$ when the cultures had reached an $\mathrm{OD}_{600}$ of 0.4 to 0.6 and the cultures were further incubated for $8 \mathrm{~h}$ at $16^{\circ} \mathrm{C}$. Crude extracts were obtained by sonication while cooling on ice. After removal of the cellular debris by centrifugation $\left(15 \mathrm{~min}, 16,000 \mathrm{~g}, 4^{\circ} \mathrm{C}\right)$, protein purification was performed by affinity chromatography on ice using Strep-TactinXT Sepharose (IBA, Göttingen, Germany). Buffer W (100 mM Tris-HCl pH 8.0, $150 \mathrm{mM} \mathrm{NaCl}, 1 \mathrm{mM}$ EDTA) was used for equilibration and washing, and buffer BXT (buffer $\mathrm{W}$ containing $50 \mathrm{mM}$ biotin) was used for elution.
The purified proteins were analyzed by SDS-PAGE. Protein concentrations were determined using the BC Protein Assay Kit (Interchim Uptima, Montlucon Cedex, France) with bovine serum albumin (BSA) as standard.

\section{Electrophoretic Mobility Shift Assays (EMSAs)}

Electrophoretic mobility shift assays were performed as described previously (Wennerhold and Bott, 2006). The DNA fragments (100 ng, 30 - $500 \mathrm{bp}$ ) were incubated with purified GabR protein $(0-2.6 \mu \mathrm{M}$ monomer) in binding buffer $(10 \mathrm{mM}$ Tris- $\mathrm{HCl}$ pH 7.5, $50 \mathrm{mM} \mathrm{NaCl}, 5 \%$ (v/v) glycerol, 0.005\% (v/v) Triton X100) for about $20 \mathrm{~min}$ at room temperature. Electrophoresis was performed using $6 \%$ or $8 \%(\mathrm{w} / \mathrm{v})$ native polyacrylamide gels in an ice bath with TB buffer ( $89 \mathrm{mM}$ Tris- $\mathrm{HCl}$ pH 8.2, $89 \mathrm{mM}$ boric acid) as running buffer. A pre-run without samples was carried out, so that buffer differences between the gel and the running buffer were adjusted $(180 \mathrm{~V}, 1.5 \mathrm{~h})$. After the pre-run, the samples were mixed with sample buffer $(0.01 \%$ (w/v) xylene cyanol, $0.01 \%$ $(\mathrm{w} / \mathrm{v})$ bromophenol blue, $20 \%(\mathrm{v} / \mathrm{v})$ glycerol, in $1 \times \mathrm{TB}$ buffer) and loaded onto the gel. Electrophoresis was performed with the same conditions as the pre-run for 40 minutes and the gels were subsequently stained with SYBR green (Sigma-Aldrich, Darmstadt, Germany).

\section{HPLC Analysis of GABA and Glucose}

For the determination of GABA and glucose in culture superntants, 1-mL culture aliquots were taken at selected time points, centrifuged for $5 \mathrm{~min}$ at $13,000 \mathrm{~g}$, and the supernatant was stored at $-20^{\circ} \mathrm{C}$. Thawed samples were filtered (0.2 $\mu \mathrm{m}$ syringe filter, Whatman ${ }^{\mathrm{TM}}$, GE Healthcare, Freiburg, Germany) prior to HPLC analysis. The GABA concentration was quantified as ortho-phthalaldehyde derivative by reverse phase chromatography using an Agilent 1290 Infinity I LC system (Agilent, Santa Clara, CA, United States) equipped with a 5micron $4.6 \times 12.5 \mathrm{~mm}$ protective column and a Zorbax Eclipse AAA 3.5 micron $4.6 \times 75 \mathrm{~mm}$ separating column. A gradient of sodium borate buffer (A: $10 \mathrm{mM} \mathrm{Na} \mathrm{HPO}_{4}, 10 \mathrm{mM} \mathrm{Na} \mathrm{B}_{4} \mathrm{O}_{7}$, $\mathrm{pH}$ 8.2) and methanol (B) was used as eluent. Starting initially with $100 \% \mathrm{~A}, \mathrm{~B}$ was increased within $9.8 \mathrm{~min}$ from $0 \%$ to $57 \%$. At $10 \mathrm{~min}, \mathrm{~B}$ was set to $100 \%$ and hold for $2.5 \mathrm{~min}$. Reequilibration to $100 \%$ A was started after $12.5 \mathrm{~min}$ and terminated after $14 \mathrm{~min}$. The ortho-phthalaldehyde derivative was detected by a fluorescence detector using an excitation wavelength of $340 \mathrm{~nm}$ and an emission wavelength of $450 \mathrm{~nm}$. The flow rate was $2 \mathrm{~mL} / \mathrm{min}$ and the temperature was kept constant at $40^{\circ} \mathrm{C}$.

Glucose was quantified essentially as described (Richhardt et al., 2012) using an Agilent LC-1100 system (Agilent, Santa Clara, CA, United States) equipped with a Carbo-Ca Guard Cartridge (Phenomenex, Aschaffenburg, Germany) and a Rezex $^{\text {TM }}$ RCM-Monosaccharide $300 \times 7.8 \mathrm{~mm}$ column (Phenomenex, Aschaffenburg, Germany). Separation was performed at $80^{\circ} \mathrm{C}$ with water as eluent at a flow rate of $0.6 \mathrm{~mL} / \mathrm{min}$. Glucose was detected with a refraction index detector $\left(35^{\circ} \mathrm{C}\right)$. Glucose was calibrated in a range of 0.1 to $8 \mathrm{~g} / \mathrm{L}$, with a retention time of $11.2 \mathrm{~min}$. 


\section{Assay for GABA Transaminase Activity}

The activity of GABA transaminase was measured as described (Marienhagen et al., 2005). Briefly, the assay buffer contained $200 \mathrm{mM}$ Tris-HCl pH 8, $0.25 \mathrm{mM}$ pyridoxal 5'-phosphate, $20 \mathrm{mM}$ GABA, and $20 \mathrm{mM}$ 2-oxoglutaric acid. To test if ammonium affects GABA transaminase activity, $30 \mathrm{mM}$ $\left(\mathrm{NH}_{4}\right)_{2} \mathrm{SO}_{4}$ was added. The reaction mixture (initial volume $10 \mathrm{ml}$ ) was preincubated for $2 \mathrm{~min}$ at $30^{\circ} \mathrm{C}$ and started by the addition of purified protein at a final concentration of $3 \mu \mathrm{g} \mathrm{mL}^{-1}$. Six $500 \mu \mathrm{l}$ samples were collected over a period of $26 \mathrm{~min}$ and the reaction was immediately terminated by mixing each sample with $300 \mu \mathrm{L}$ of $5 \%(\mathrm{v} / \mathrm{v})$ perchloric acid and 38\% (v/v) ethanol. After this, the sample was neutralized by addition of $200 \mu \mathrm{L}$ of $20 \mathrm{mM}$ Tris- $\mathrm{HCl}(\mathrm{pH} 8)$ with $23 \mathrm{mM} \mathrm{K}_{2} \mathrm{CO}_{3}$. The precipitated salts were removed by centrifugation $(10 \mathrm{~min}, 16,000 \mathrm{~g}$ ). Subsequently, the glutamate concentration in the sample was measured by HPLC (Agilent 1260 series) equipped with an Agilent Eclipse XDB-C18 column using a variable wavelength detector and a fluorescence detector. Elution was performed with a mixture of $43 \%(\mathrm{v} / \mathrm{v})$ buffer A [10 mM Na $2 \mathrm{HPO}_{4}, 10 \mathrm{mM} \mathrm{Na}_{2} \mathrm{~B}_{4} \mathrm{O}_{2}(\mathrm{pH} \mathrm{8.2)}]$ and $57 \%$ $(\mathrm{v} / \mathrm{v})$ methanol at a flow rate of $2 \mathrm{~mL} / \mathrm{min}$ for 14 minutes. Before chromatographic separation, amino acids were derivatized with $o$-phthaldialdehyde (Lindroth and Mopper, 1979). 25-1000 $\mu \mathrm{M}$ sodium glutamate was used as standard.

\section{RESULTS}

\section{Transcriptome Comparison of WT Cells Grown With GABA or Glucose}

To analyze the influence of GABA on global gene expression, we compared the transcriptomes of cells cultivated in modified CGXII minimal medium lacking $\left(\mathrm{NH}_{4}\right)_{2} \mathrm{SO}_{4}$ and containing either GABA or glucose as carbon source. In GABA-grown cells, 163 genes showed $a \geq 2$-fold increased mRNA level and 71 genes $a \geq 2$-fold lowered mRNA level compared to glucose-grown cells (Supplementary Table 2). The genes showing the by far strongest upregulation in GABA-grown cells were gabTDP (87-, 78-, and 65-fold, respectively) (Figure 2 and Supplementary Table 2). Interestingly, also expression of the gabR gene located upstream and divergent to gabTDP was four-fold increased in GABA-grown cells. The gabR gene encodes a transriptional regulator (see below). Among the other genes upregulated in GABA-grown cells, only cg0083 encoding a putative nicotinamide mononucleotide transporter showed a more than 10-fold increased expression. In general, the upregulated genes belonged to a large variety of functional categories and the same holds true for the genes downregulated in GABA-cultivated cells. The latter group included at least 30 genes for proteins involved in transport, including those for phosphate uptake (pitA, pstSCAB), genes involved in amino acid biosynthesis (leuCD, serA, metE, $\arg C$, aroG, $g \ln A$ ), and genes involved in lactate metabolism (cg3226, lldD). In summary, this experiment demonstrated that the gabTDP genes were strongly induced in the presence of GABA, indicating that they are subject to transcriptional control. All other differentially expressed genes were significantly less changed under this condition.

\section{Genomic Location and Conservation of the gabR-gabTDP Gene Cluster}

The $g a b R$ gene is located upstream and divergent to gabTDP and encodes a transcriptional regulator, which might regulate these genes. To check whether this genomic organization is conserved in related species, which is a hint for a regulatory relationship between these genes, we analyzed the presence and organization of the gabR-gabTDP gene cluster in other organisms. As shown in Figure 3, similar gene clusters were found in a number of Corynebacterium species and, in a different organization, also in some Rhodococcus and Mycobacterium species. Interestingly, additional copies of $g a b R$ and $g a b T$ are present immediately adjacent to the gabRgabTDP gene cluster in Corynebacterium aurimucosum. GabR and its homologs from Actinobacteria belong to the PucR protein family (Pfam PF07905) and have a C-terminal DNAbinding HTH motif. The best characterized representative of this family is PucR of B. subtilis, which is involved in the regulation of purine catabolism (Schultz et al., 2001; Beier et al., 2002).

\section{Relevance of gabR and the gabTDP Operon for Growth With GABA}

To investigate whether GabR is involved in the regulation of GABA metabolism, we generated the deletion mutant C. glutamicum $\triangle$ gabR and compared it with the WT. Both strains grew identically with glucose, but the $\triangle g a b R$ mutant had lost the ability to grow with GABA as sole carbon and nitrogen source (Figure 4A). The growth defect of the $\triangle g a b R$ strain with GABA was abolished after transformation with the expression plasmid pAN6-gabR harboring $g a b R$ under control of a leaky tac promoter (Figure 4B), which confirmed that the loss of GabR was responsible for the observed phenotype. Whereas full complementation was achieved by basal gabR expression in the absence of IPTG, induction of plasmid-borne gabR expression with $50 \mu \mathrm{M}$ IPTG had a negative effect on growth of the $\triangle g a b R$ mutant and the WT in comparison to the non-induced cultures (Supplementary Figure 1). This might be a consequence of too strong expression of the gabTDP operon causing e.g., membrane-stress by overexpression of the permeaseencoding gene gabP or metabolic disturbances by an excessive GABA metabolism.

In a further experiment, we tested whether growth of the $\triangle g a b R$ strain on GABA can be restored by plasmid-based expression of gabTDP. C. glutamicum WT and the $\triangle g a b R$ mutant were transformed with pAN6-gabTDP and cultivated with GABA as sole carbon and nitrogen source and different IPTG concentrations (Figure 4C). Without IPTG addition, the $\triangle g a b R$ strain with pAN6-gabTDP grew very slowly. Addition of $10 \mu \mathrm{M}$ IPTG significantly improved the growth of this strain and with $100 \mu \mathrm{M}$ IPTG it grew comparably to the WT carrying pAN6-gabTDP. These results suggest that gabTDP 


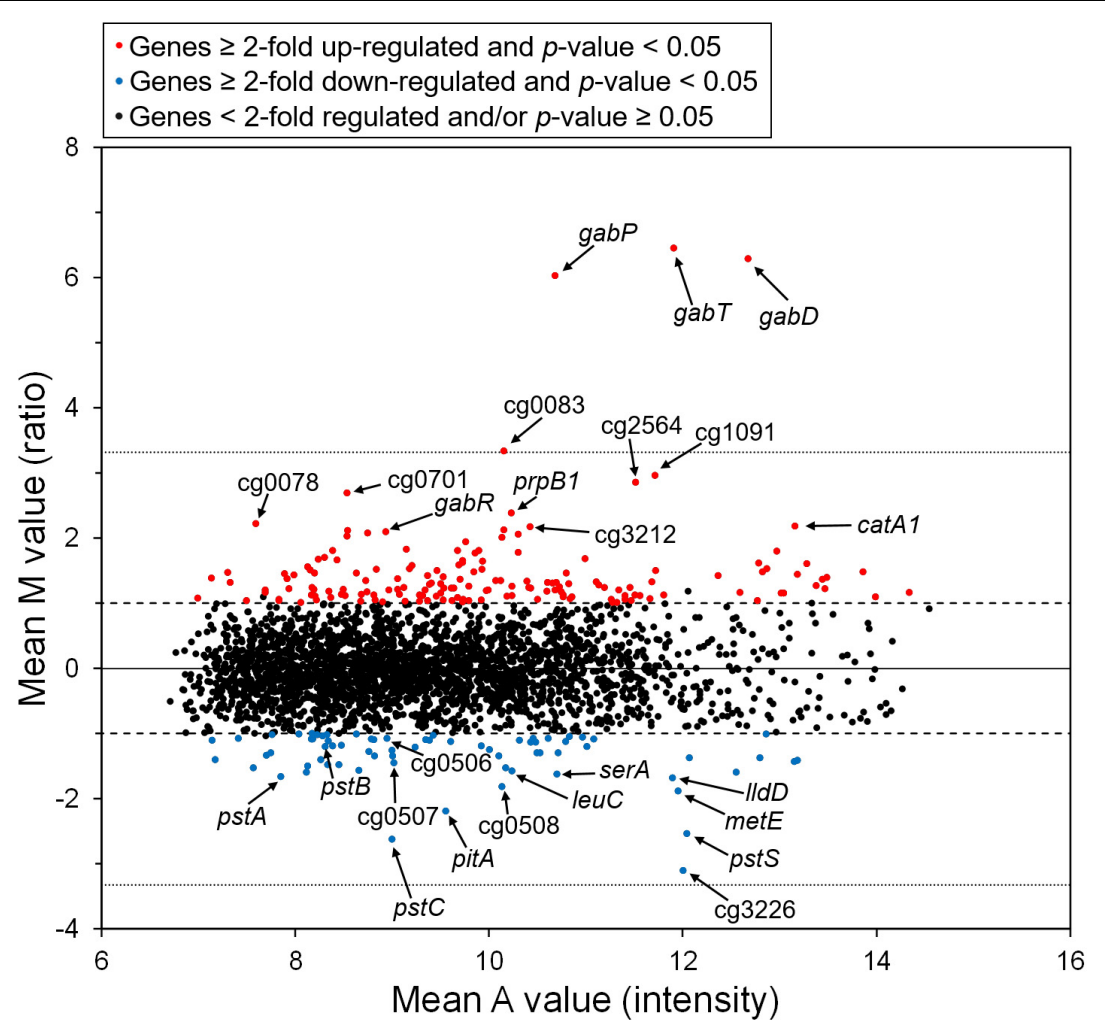

FIGURE 2 | M/A plot showing differential gene expression in C. glutamicum WT cells grown with GABA and urea compared to WT cells grown with glucose and urea. The data shown are based on four two-channel DNA microarray hybridizations starting with cDNA from four independent biological replicates. The dashed lines indicate a 2 -fold altered mRNA ratio, the dotted lines a 10-fold altered mRNA ratio.

are the only genes required for growth with GABA that are controlled by GabR.

\section{Purification of GabR and Determination of the Native Size}

The growth experiments with the $\triangle g a b R$ mutant showed that GabR activates gabTDP expression. To get further insights into the regulatory mechanism, we purified GabR for interaction studies with the $\mathrm{P}_{\text {gabTDP }}$ promoter by EMSAs. GabR was overproduced in E. coli BL21(DE3) and purified by means of an N-terminal decahistidine tag and Ni-NTA affinity chromatography (Figure 5A). The tag was cleaved off with TEV protease followed by size exclusion chromatography to further purify GabR and determine its native size and oligomeric state (Figure 5B). The peak of GabR appeared at an elution volume of $10.67 \mathrm{~mL}$. Based on the calibration curve ( $\mathrm{K}_{\mathrm{av}}$ versus $\left.\log \mathrm{M}_{\mathrm{r}}\right)$ derived from the standard proteins (Figure 5C), the native size of GabR was calculated to be $420 \mathrm{kDa}$. Since the theoretical mass of GabR is $55.75 \mathrm{kDa}$, the native size suggests that C. glutamicum GabR forms an octamer (theoretical mass $446 \mathrm{kDa}$ ).

\section{Determination of Transcriptional Start Sites}

In a previous RNAseq study, a TSS of $\mathrm{P}_{g a b R}$ was identified, but no TSS of $\mathrm{P}_{\text {gabTDP }}$, presumably because the latter genes were not expressed in the absence of GABA (Pfeifer-Sancar et al., 2013). Therefore, we determined the TSS of $\mathrm{P}_{\text {gabTDP }}$ initially using a $5^{\prime} / 3^{\prime}$-RACE kit and identified a single TSS for gabT located $36 \mathrm{bp}$ upstream of the gabT start codon (Figure 6A). The -10 region (TACTCA) and the -35 region (TTAACT) of $\mathrm{P}_{\text {gabTDP }}$ and the RBS of $g a b T$ (AGGAG) were predicted according to known consensus sequences (Pfeifer-Sancar et al., 2013). In an alternative approach, we performed RNAseq of GABA-grown WT cells to identify TSSs. For gabT, the transcriptional start site found by $5^{\prime} / 3^{\prime}$ RACE was confirmed with 43906 reads starting at this position. Interestingly, another TSS was identified within the gabD coding region. 28 reads started 210 bp upstream of the gabP start codon, suggesting the presence of an additional weak promoter for gabP expression. The deduced -10 region (AACAAT) and -35 region (TTCGGC) showed reasonable similarity to the reported consensus sequences (Pfeifer-Sancar et al., 2013). This promoter might allow GabR-independent weak expression of gabP and could enable initial GABA uptake to allow GabR-dependent expression of the gabTDP operon. With respect to the TSS of $g a b R$, the RNAseq data revealed only two reads that started at the position 59 bp upstream of the gabR start codon (Figure 6A) that was previously reported (Pfeifer-Sancar et al., 2013). Four reads started 11 bp upstream of the gabR start codon, suggesting either another very weak promoter for $g a b R$ expression with weakly conserved -10 region (TAATTG) and -35 region (TTGTAG) 


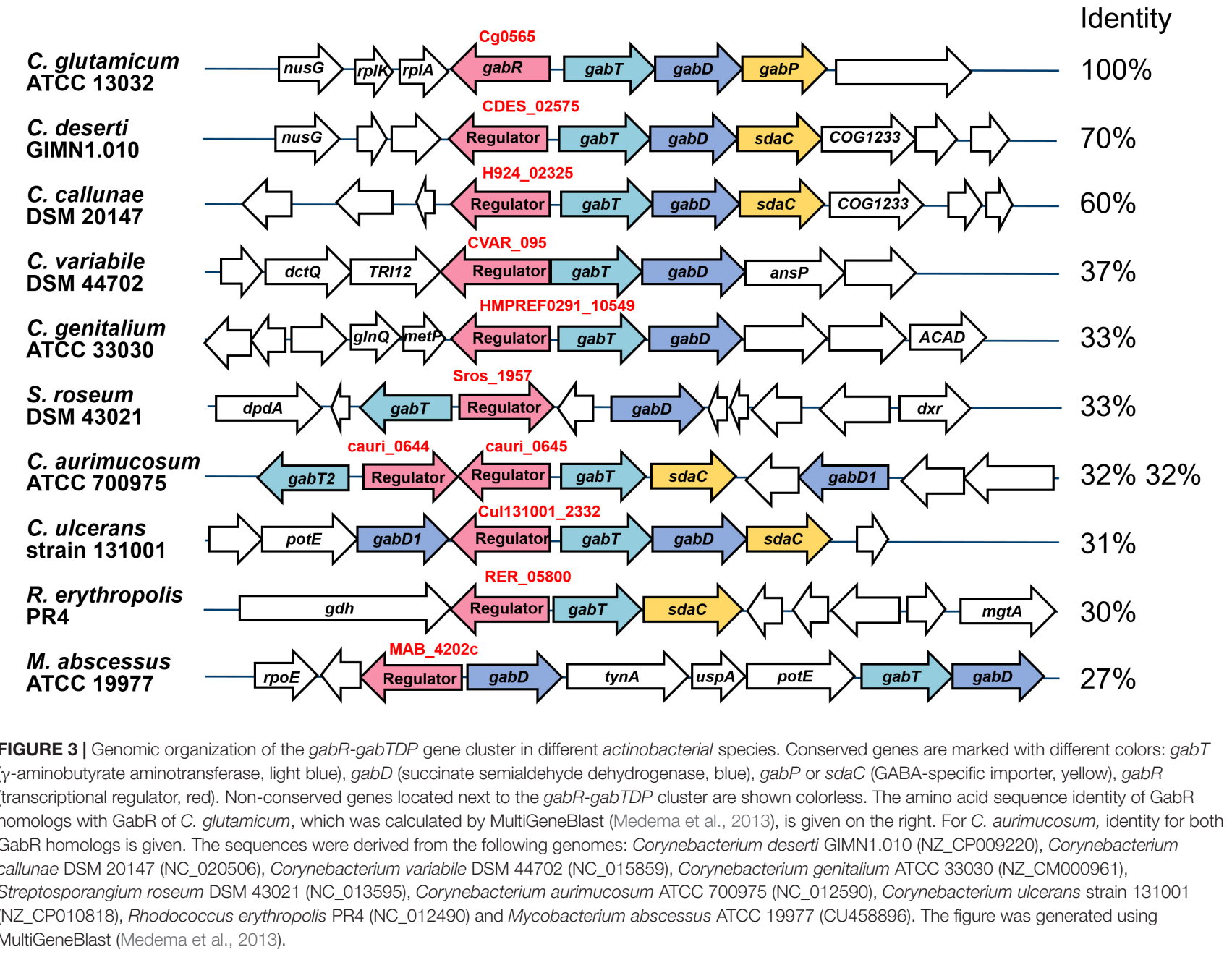

or processing of the transcript starting 59 bp upstream of the gabR start codon.

\section{Determination of the GabR Binding Site(s) in the gabTDP Promoter Region}

For the determination of the GabR binding site, EMSAs were performed with purified GabR. In the first experiment, binding of GabR to a $500 \mathrm{bp}$ fragment covering the entire gabR-gabT intergenic region was analyzed using a DNA fragment of similar size of the $l d h A$ gene of C. glutamicum as negative control. The $g a b R-g a b T$ intergenic region was shifted partially with $80 \mathrm{nM}$ GabR (monomer) and fully with 240 nM GabR (Supplementary Figure 2), whereas no shift was observed for the control fragment up to $320 \mathrm{nM}$ GabR (Supplementary Figure 2). This suggests that GabR binds specifically to the gabTDP promoter region. In the following, we reduced the size of the DNA fragments step by step to localize the binding site(s) of GabR using the above mentioned fragments as positive and negative controls. As shown in Supplementary Figure 3, a full shift was observed for fragments FA1 and FA2, a partial shift for FA3, and a very poor shift for FA4 and FA5. For the fragments starting at the other side of the promoter region, clear shifts were observed for fragments FB1, FB2 and FB3, weak shifts for FB4 and FB5, and no shift for FB6. These results suggested that GabR binds between position -87 and -23 with respect to the TSS of gabT.

Regulator binding sites are often conserved among closely related species, which is useful to identify a binding motif when only a single target promoter is known (Wennerhold et al., 2005). We searched for a binding motif in the gabR-gabT intergenic regions of C. glutamicum, Corynebacterium deserti, and Corynebacterium callunae using MEME software (Bailey et al., 2006). The search uncovered a 21 bp inverted repeat that was present 1-2 times in each input sequence (Figure 6C). An alignment of the input sequences (Supplementary Figure 4) revealed that the regions encompassing the two proposed GabR binding motifs belong to the more conserved regions, which is a further hint that these represent GabR binding sites.

In further EMSAs, we used 55 bp fragments to verify the localization of the GabR binding sites in the C. glutamicum gabTDP promoter. FS1 is a fragment covering both of the predicted binding sites, whereas FS2 covers half of the first 

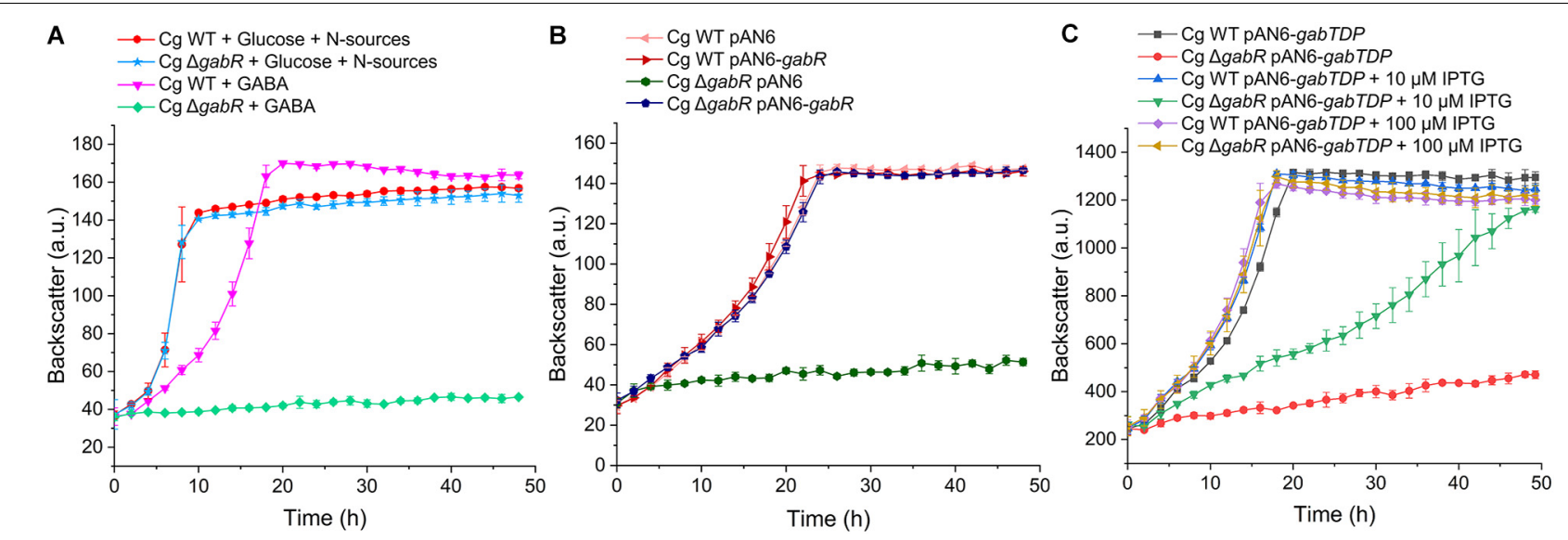

FIGURE 4 | Growth studies with C. gutamicum WT and the $\triangle$ gabR mutant with or without the plasmids pAN6, pAN6-gabR, or pAN6-gabTDP. All strains were precultivated in BHIS medium and washed with phosphate buffer before inoculation of the main culture. Growth experiments were performed in a BioLector microcultivation system using 48-well Flower plates containing $750 \mu \mathrm{l} \mathrm{CGXII} \mathrm{minimal} \mathrm{medium} \mathrm{with} 62.5 \mathrm{mM}$ GABA as sole carbon and nitrogen source or with $41.7 \mathrm{mM}$ glucose as carbon source and $151 \mathrm{mM}\left(\mathrm{NH}_{4}\right)_{2} \mathrm{SO}_{4}$ and $83 \mathrm{mM}$ urea as nitrogen sources. (A) Growth of the C. g/utamicum $\Delta$ gabR mutant compared to the WT with glucose or GABA as carbon sources. (B) Influence of plasmids pAN6 and pAN6-gabR on growth of $C$. glutamicum WT and the $\triangle$ gabR mutant with GABA as sole carbon and nitrogen source. (C) Influence of plasmids pAN6 and pAN6-gabTDP on growth of C. glutamicum WT and the $\triangle$ gabR mutant with GABA as sole carbon and nitrogen source. Where indicated, $10 \mu \mathrm{M}$ or $100 \mu \mathrm{M}$ IPTG was added to the medium for induction of the $\mathrm{P}_{\text {tac }}$ promoter controlling expression of gabTDP. Since the promoter of pAN6 is known to be slightly leaky, basal transcription of the target genes is independent of IPTG addition. Mean values and standard deviations of three biological replicates are shown.
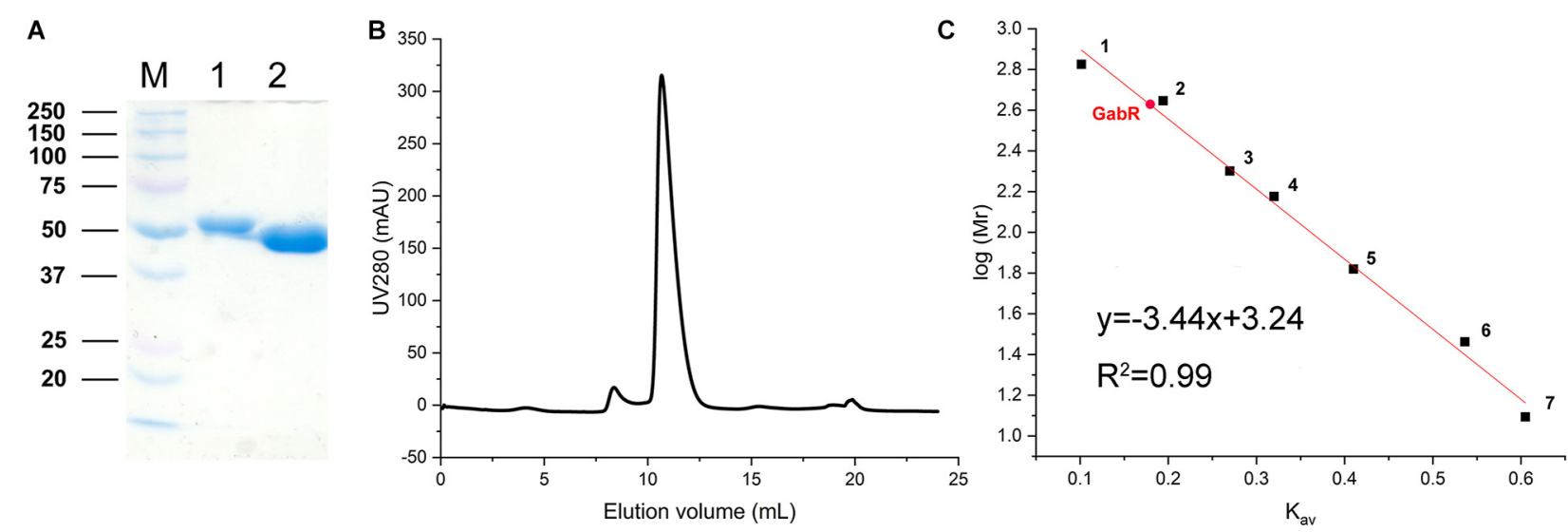

FIGURE 5 | Purification of GabR and determination of its native molecular mass. (A) Coomassie-stained SDS-polyacrylamide gel showing marker proteins (M, molecular mass in kDa) and GabR after Ni-NTA affinity chromatography (lane 1) and after His-tag removal with TEV protease (lane 2). (B) Size exclusion chromatography of tag-free GabR using a Superdex 200 Increase 10-300GL column (GE Healthcare). Protein was detected by absorbance at $280 \mathrm{~nm}$.

(C) Calibration curve for the Superdex column obtained with standard proteins: 1, thyroglobulin (669 kDa); 2, apoferritin (443 kDa); 3, amylase (200 kDa); 4, alcohol dehydrogenase (150 kDa); 5, bovine serum albumin (66 kDa); 6, carbonic anhydrase (29 kDa); 7, cytochrome c (12.4 kDa). The Kav value determined for GabR is marked with a red dot.

binding site and the entire second binding site (Figure 6A). A $55 \mathrm{bp}$ fragment downstream of the predicted binding sites was used as negative control. Binding of GabR was observed for both FS1 and FS2, but it was stronger for FS1 (Figure 6B). This suggests that one complete binding site is sufficient for weak binding, but two sites are required for strong binding by GabR. In another experiment, binding of GabR to two $31 \mathrm{bp}$ fragments (FS3 and FS4) covering one binding site each was tested. A 31 bp fragment downstream of the predicted binding sites was used as negative control. Reasonable binding was observed for FS3 containing the first binding site and weak binding, not much stronger compared to the negative control, was observed for FS4 (Supplementary Figure 5). The band of the complex did not run far into the gel, presumably because of the large size of the GabR octamer. We assume that this band represents the complex, as it was absent from the negative control and from the DNA samples without protein. Our results suggest that each of the two binding sites can be bound separately by GabR, but binding is much stronger when both binding sites are present. 
A

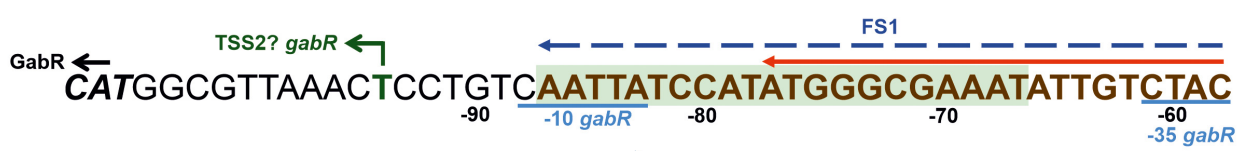

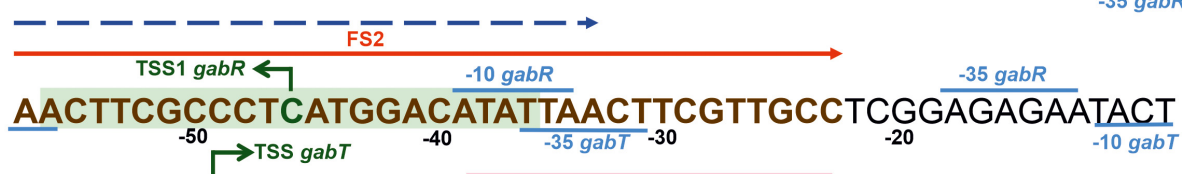

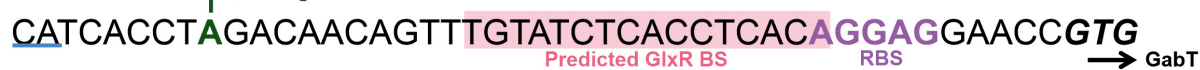

B

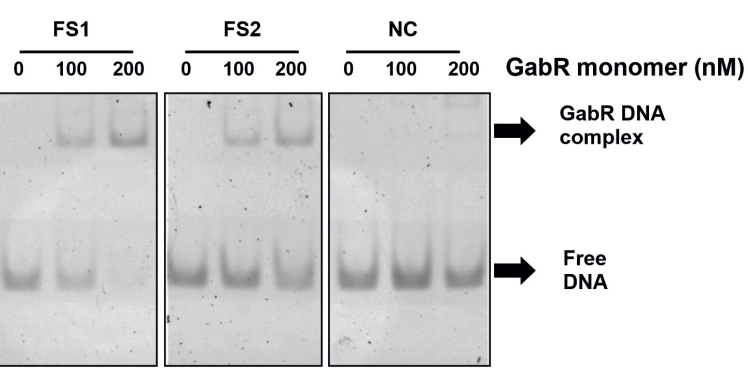

C

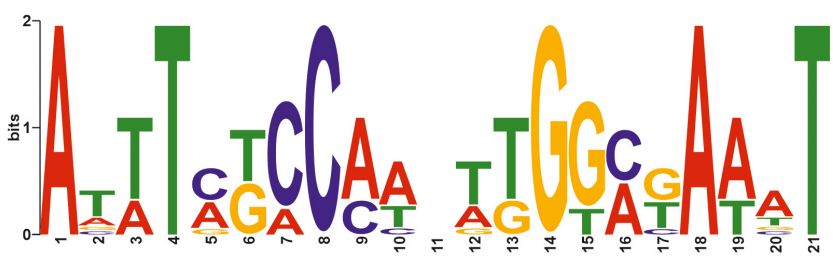

FIGURE 6 | Determination of the binding site(s) of GabR in the gabTDP promoter region. (A) Sequence of the gabR-gabT intergenic region. The ATG start codon of gabR (cg0565) and the GTG start codon of gabT (cg0566) are shown in bold and italic. The transcriptional start sites of gabR and gabT are indicated with green arrows. The corresponding -10 and -35 regions are labeled in blue. The ribosome binding site of gabTDP is labeled in purple, and the predicted GlxR binding site is marked with light red background. The binding region for GabR determined in this work by EMSAs is marked in bold brown letters (compare Supplementary Figure 3). Fragments FS1 (-87 to -33) and FS2 (-77 to -23$)$ are marked in the figure by a blue or red arrow, respectively. Potential binding sites for GabR are marked with light green background. (B) EMSAs with purified GabR and DNA fragments FS1 and FS2. The fragments were incubated with the indicated GabR concentrations (given in $\mathrm{nM}$ of monomers). A 55 bp fragment downstream of the predicted binding sites was used as negative control (NC). (C) Proposed GabR consensus binding site identified with MEME software using the gabR-gabT intergenic regions of $C$. glutamicum WT, Corynebacterium deserti and Corynebacterium callunae as input sequences.
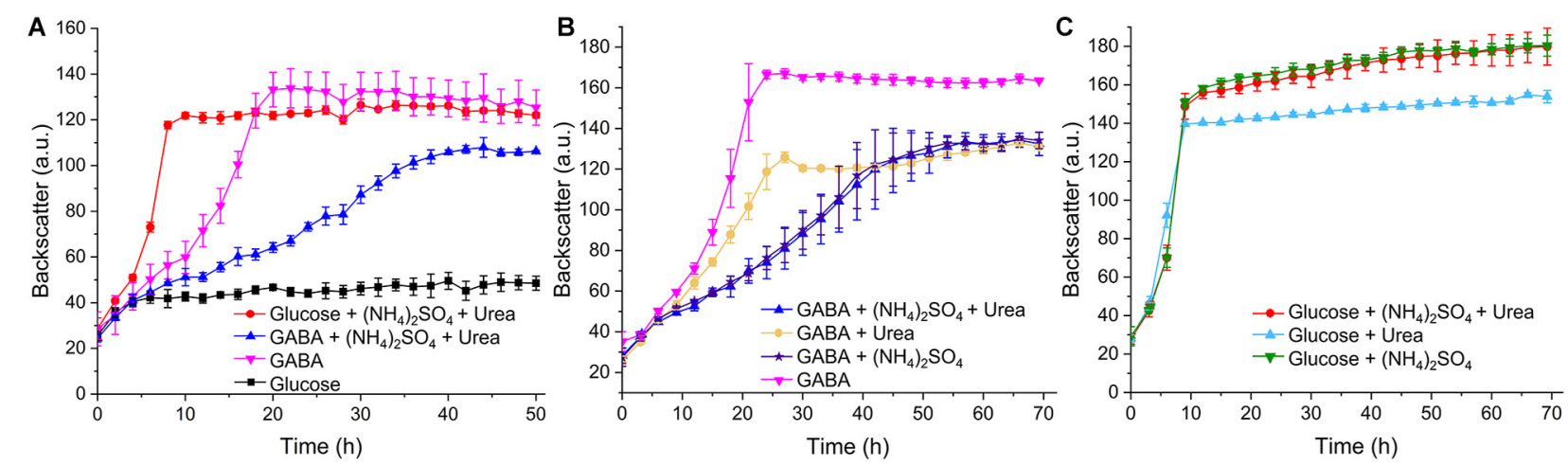

FIGURE 7 | Growth of C. glutamicum WT with different carbon and nitrogen sources. Cells were precultured in BHIS medium for $12 \mathrm{~h}$ and subsequently washed with phosphate buffer before inoculation of the main cultures to a starting $\mathrm{OD}_{600}$ of 0.5 . The main cultivation was performed in a BioLector microcultivation system with 48-well Flower plates each containing $750 \mu \mathrm{L}$ CGXII minimal medium supplemented with $41.7 \mathrm{mM}$ glucose or $62.5 \mathrm{mM} \mathrm{GABA}$. $\left.151 \mathrm{mM}_{(\mathrm{NH}}\right)_{2} \mathrm{SO}_{4}$ or $83 \mathrm{mM}$ urea were included as indicated in panels (A-C). Mean values and standard deviations of three biological replicates are shown.

To verify that both binding sites are relevant for good binding, we mutated four conserved bases of both motifs either separately or in combination in fragment FS1 and analyzed the binding by GabR (Supplementary Figure 6). Mutation of one of the binding sites reduced the affinity to GabR, and with both binding sites mutated, the binding was almost completely abolished. This verifies that both sites are relevant for GabR binding.

\section{Influence of Ammonium and Urea on}

\section{Growth of C. glutamicum With GABA}

In our initial growth studies using the BioLector microcultivation system, C. glutamicum WT was cultivated in standard CGXII minimal medium containing either glucose $(41.7 \mathrm{mM}$ corresponding to $250 \mathrm{mM}$ carbon) or GABA (62.5 mM corresponding to $250 \mathrm{mM}$ carbon) as carbon sources. In 
glucose-containing medium, a growth rate $\mu$ of $0.4 \mathrm{~h}^{-1}$ was observed, whereas it was only $0.05 \mathrm{~h}^{-1}$ in GABA-containing medium. Interestingly, a growth rate of $0.13 \mathrm{~h}^{-1}$ was obtained when the standard nitrogen sources of CGXII medium, ammonium sulfate $(151 \mathrm{mM})$ and urea $(83 \mathrm{mM})$, were omitted and GABA served as sole carbon and nitrogen source (Figure 7A). Measurement of the final $\mathrm{OD}_{600}$ in a spectrophotometer after $50 \mathrm{~h}$ revealed no significant difference between the cultures with glucose, $\left(\mathrm{NH}_{4}\right)_{2} \mathrm{SO}_{4}$ and urea on the one hand $\left(\mathrm{OD}_{600}=12.17 \pm 0.54\right)$ and the cultures with GABA without additional nitrogen sources on the other hand $\left(\mathrm{OD}_{600}=11.81 \pm 0.96\right)$. Further growth experiments revealed that $\left(\mathrm{NH}_{4}\right)_{2} \mathrm{SO}_{4}$ alone was sufficient to exert the same inhibitory effect on growth with GABA $\left(\mu=0.04 \mathrm{~h}^{-1}\right)$ as in combination with urea $\left(\mu=0.05 \mathrm{~h}^{-1}\right.$ ) (Figure 7B). Urea alone was also inhibitory, but to a lesser extent $\left(\mu=0.08 \mathrm{~h}^{-1}\right)$. Urea is converted by urease to ammonium and carbon dioxide (Siewe et al., 1998), but the ammonia levels formed in this way are probably lower than in media containing $\left(\mathrm{NH}_{4}\right)_{2} \mathrm{SO}_{4}$, which could explain the weaker inhibitory effect of urea. When similar experiments were performed with glucose as carbon source, all cultures grew with the same rate (Figure 7C). A further experiment revealed that the inhibitory effect of $\left(\mathrm{NH}_{4}\right)_{2} \mathrm{SO}_{4}$ on growth with GABA was concentration-dependent and weak inhibition was observed already with $10 \mathrm{mM}\left(\mathrm{NH}_{4}\right)_{2} \mathrm{SO}_{4}$ (Supplementary Figure 7). The negative influence of $151 \mathrm{mM}$ $\left(\mathrm{NH}_{4}\right)_{2} \mathrm{SO}_{4}$ on the final backscatter during growth with GABA as sole carbon source varied throughout our study. Sometimes the same final backscatter was reached in the presence of $\left(\mathrm{NH}_{4}\right)_{2} \mathrm{SO}_{4}$ as in its absence, whereas in other experiments the final backscatter was much lower in the presence of $\left(\mathrm{NH}_{4}\right)_{2} \mathrm{SO}_{4}$. The reason for this variability is currently unknown. In summary, C. glutamicum grew quite well in minimal medium with GABA as sole carbon and nitrogen source and the additional presence of ammonium was inhibitory. In the following studies, we searched for the basis of ammonium inhibition.

\section{Influence of Ammonium on GABA Consumption}

To test the influence of ammonium on GABA consumption, the WT was cultured in shake flasks with minimal medium containing either GABA or GABA plus $\left(\mathrm{NH}_{4}\right)_{2} \mathrm{SO}_{4}$. With GABA as sole carbon and nitrogen source, a growth rate of $0.12 \mathrm{~h}^{-1}$ was observed, which was reduced to $0.08 \mathrm{~h}^{-1}$ in the presence of $151 \mathrm{mM}\left(\mathrm{NH}_{4}\right)_{2} \mathrm{SO}_{4}$ (Figure 8A). In the absence of $\left(\mathrm{NH}_{4}\right)_{2} \mathrm{SO}_{4}$, GABA $(62.5 \mathrm{mM})$ was completely consumed after $24 \mathrm{~h}$ and only after about $36 \mathrm{~h}$ in the presence of $\left(\mathrm{NH}_{4}\right)_{2} \mathrm{SO}_{4}$. Both cultures reached a final $\mathrm{OD}_{600}$ of about 11 , corresponding to $2.75 \mathrm{~g}$ cell dry weight/L (Kabus et al., 2007). In a further experiment, cells were cultivated in minimal medium containing either GABA and glucose or GABA, glucose, and $\left(\mathrm{NH}_{4}\right)_{2} \mathrm{SO}_{4}$. In this case, the cultures with $\left(\mathrm{NH}_{4}\right)_{2} \mathrm{SO}_{4}$ grew slightly faster $\left(\mu=0.46 \mathrm{~h}^{-1}\right)$ than the ones without $\left(\mathrm{NH}_{4}\right)_{2} \mathrm{SO}_{4}\left(\mu=0.39 \mathrm{~h}^{-1}\right)$ and also consumed glucose faster than the cultures without $\left(\mathrm{NH}_{4}\right)_{2} \mathrm{SO}_{4}$ (Figure 8B). Complete glucose consumption was observed after $8 \mathrm{~h}$ and $10 \mathrm{~h}$, respectively. Interestingly, GABA consumption was comparable for the cultures with and without $\left(\mathrm{NH}_{4}\right)_{2} \mathrm{SO}_{4}$, in contrast to the cultures without glucose, and complete GABA consumption was observed after $12 \mathrm{~h}$. It is obvious from Figure $\mathbf{8 B}$ that glucose and GABA are used simultaneously, also in the presence of $\left(\mathrm{NH}_{4}\right)_{2} \mathrm{SO}_{4}$.

\section{Relevance of Ammonia-Assimilating Enzymes for Growth With GABA}

During growth in minimal medium with GABA as sole carbon and nitrogen source, L-glutamate is formed from 2-oxoglutarate by the GABA transaminase GabT. L-Glutamine synthesis is dependent on glutamine synthetase encoded by the $g \ln A$ gene (Jakoby et al., 1997). A second putative glutamine synthetase is encoded by $g \ln A 2$, but this gene cannot complement the glutamine auxotrophy of a $\Delta g \ln A$ mutant and the function of the GlnA2 protein is not known yet (Nolden et al., 2001; Rehm and Burkovski, 2011). Glutamine synthetase requires L-glutamate, ATP and $\mathrm{NH}_{4}{ }^{+}$as substrates. Therefore, the question arises which reactions lead to ammonia release and thereby allow glutamine synthesis during growth with GABA as sole nitrogen source. A reasonable candidate is glutamate dehydrogenase $(\mathrm{Gdh})$, which catalyzes the reductive amination of 2-oxoglutarate with ammonia and NADPH to L-glutamate and $\mathrm{NADP}^{+}$, and also the reverse reaction (Shiio and Ozaki, 1970). In order to determine whether Gdh is important as provider of ammonium during growth on GABA, we tested a $\Delta g d h$ mutant and found that it grew similarly as the wild type with GABA as sole carbon and nitrogen source (data not shown). This does not exclude the Gdh reaction as a source of ammonia, but shows that alternative ways for ammonium generation exist.

Besides the $\Delta g d h$ mutant, we also tested the growth behavior on GABA of other mutants with defects in nitrogen assimilation, which are mutants lacking either glutamate synthase $(\triangle g l t B D)$, or glutamine synthetase $(\triangle g \ln A)$, or a triple mutant devoid of $\mathrm{G} \ln \mathrm{A}$, GlnA2, and Gdh $(\triangle g \ln A \mathrm{D} g \ln A 2 \mathrm{D} g d h)$. Whereas the $\triangle g l t B D$ mutant grew like the WT, the other two mutants were unable to grow with GABA as sole carbon and nitrogen source, irrespective of the absence or presence of ammonium. In Figure 9, the data for the triple mutant are shown. The result corresponds to the expectation that GltBD is not required for glutamate synthesis, whereas GlnA is essential for glutamine synthesis. This was further confirmed by supplementing GABA medium with L-glutamine, which rescued growth of the triple mutant (Figure 9). The addition of L-glutamine also improved the growth rate of the WT with GABA by about $50 \%\left(\mu=0.15 \mathrm{~h}^{-1}\right.$ vs. $\mu=0.10 \mathrm{~h}^{-1}$ without glutamine) and the final backscatter by about 25\% (Figure 9). C. glutamicum is able to use L-glutamine as sole carbon and nitrogen source (Rehm et al., 2010). Whereas the increased final backscatter can be explained by the use of L-glutamine as additional carbon source, the increased growth rate suggests a deficiency in glutamine availability when GABA serves as sole nitrogen source. Interestingly, when $\left(\mathrm{NH}_{4}\right)_{2} \mathrm{SO}_{4}$ was added to medium with GABA and glutamine, it again had a negative effect on growth of both the WT and the triple mutant (Figure 9). This suggests that the inhibitory effect of ammonium 

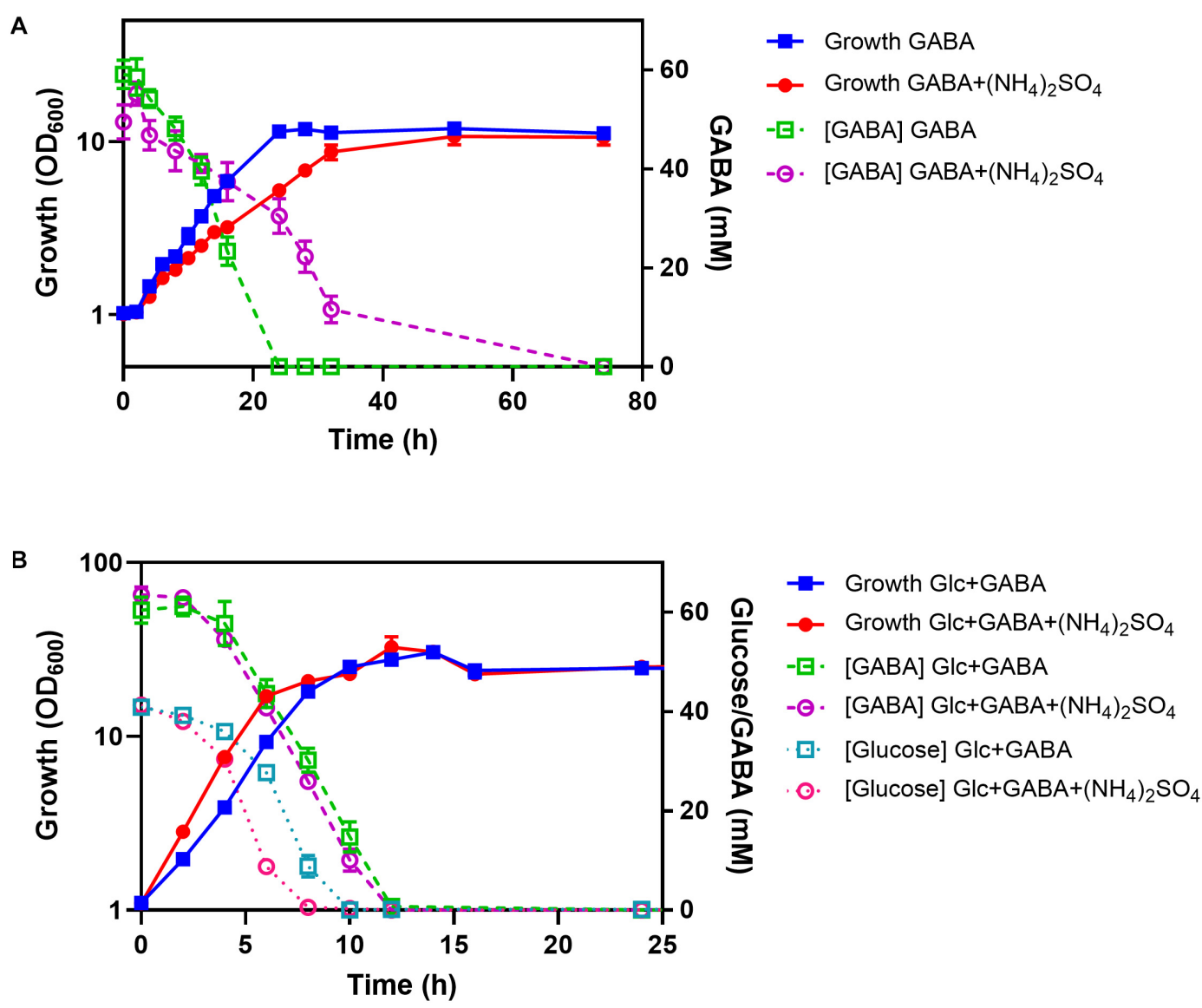

FIGURE 8 | Influence of $\left(\mathrm{NH}_{4}\right)_{2} \mathrm{SO}_{4}$ on GABA consumption in the absence (A) and presence (B) of glucose (Glc). C. glutamicum WT was cultured in shake flasks containing CGXII medium with the indicated carbon and nitrogen sources $\left(62.5 \mathrm{mM}\right.$ GABA, $\left.41.7 \mathrm{mM} \mathrm{glucose}, 151 \mathrm{mM}\left(\mathrm{NH}_{4}\right)_{2} \mathrm{SO}_{4}\right)$. Glucose and $\mathrm{GABA}$ concentrations were determined by HPLC. Mean values and standard deviations of three biological replicates are shown.

on growth with GABA alone is not due to a negative effect on glutamine synthesis.

\section{Influence of Growth Conditions and GabR on the Promoter Activity of $\mathbf{P}_{\text {gabTDP }}$}

To analyze the influence of ammonia and other conditions on the expression of the gabTDP operon, we constructed the reporter plasmid pJC1- $\mathrm{P}_{g a b T}$-eYFP containing a transcriptional fusion between $\mathrm{P}_{\text {gabTDP }}$ (500 bp upstream of the gabT start codon) and the eYFP-encoding gene. Thereby the promoter activity can be monitored by measuring the fluorescence of the culture. Cell density (backscatter) and eYFP fluorescence of WT cells with pJC1- $\mathrm{P}_{g a b T}$-eYFP cultivated in different media is shown in Figures 10A,B. As the cells reached different final backscatter values, the specific fluorescence (representing the ratio of fluorescence/backscatter) was calculated for the cultures in the stationary phase at $40 \mathrm{~h}$, which represents the activity of $\mathrm{P}_{\text {gabTDP }}$ over the entire cultivation (Figure 10C). We also checked the specific fluorescence of the cultures in the exponential growth phase, which was very similar to the values after $40 \mathrm{~h}$ (data not shown). Maximal specific fluorescence $(2.81 \pm 0.07)$ was observed for the cultures grown with GABA alone, whereas it was almost zero $(0.03 \pm 0.00)$ for the cultures grown with glucose alone, indicating that $\mathrm{P}_{\text {gabTDP }}$ was active only in the presence of GABA. The specific fluorescence of the cultures grown with GABA, ammonium sulfate and urea $(1.84 \pm 0.10)$ was reduced by $35 \%$ in comparison to the cultures with GABA alone, indicating that ammonium inhibited transcription of gabTDP. Addition of glutamine to a culture with GABA and ammonium sulfate did not enhance gabTDP expression (data not shown), suggesting that glutamine does not influence transcription of gabTDP.

The specific fluorescence of cells cultivated with GABA, glucose, ammonium sulfate and urea $(0.90 \pm 0.02)$ was reduced by even $68 \%$ compared to growth on GABA alone, indicating that not only ammonium, but also glucose had a negative effect on gabTDP transcription. This effect was not specific for glucose, as it was also observed with gluconate or myo-inositol as additional carbon sources (Supplementary Figure 8).

In further experiments, we analyzed the activity of $\mathrm{P}_{\text {gabTDP }}$ in the $\triangle g a b R$ mutant (Figures 10D,E). In medium with only GABA as carbon and nitrogen source, the mutant showed neither growth nor fluorescence, as expected. In medium with glucose and GABA, the mutant was able to grow, but no fluorescence was 


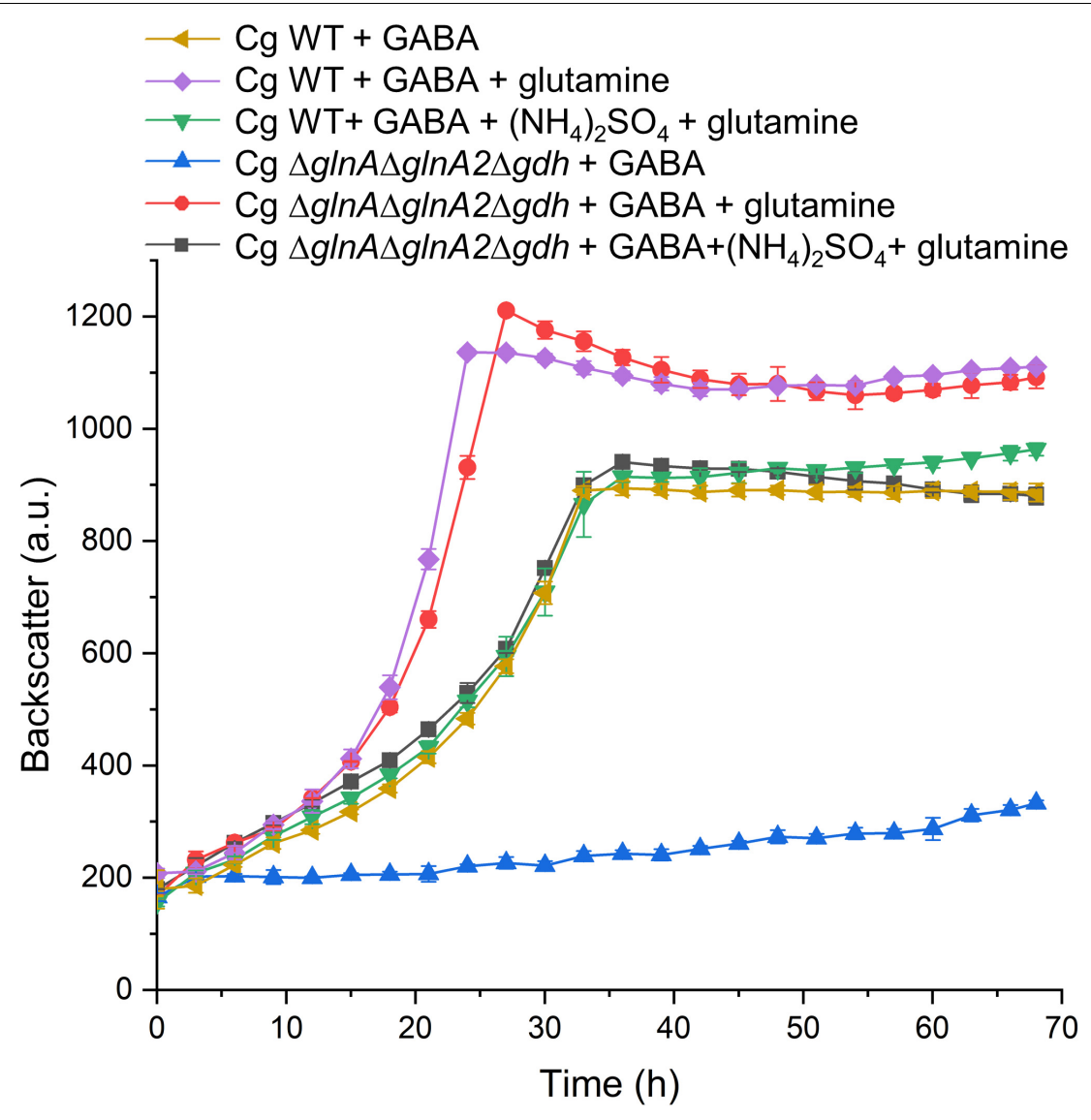

FIGURE 9 | Influence of L-glutamine supplementation on growth of C. glutamicum WT and the $\Delta g \ln A \Delta g / n A 2 \Delta g d h$ mutant in CGXII medium with GABA. Cells were precultured in BHIS medium for $12 \mathrm{~h}$ and subsequently washed with phosphate buffer before inoculation of the main cultures to a starting $\mathrm{OD}_{600}$ of 0.5 . The main cultivation was performed in a BioLector microcultivation system with 48-well Flower plates each containing $750 \mu \mathrm{L}$ CGXII minimal medium supplemented with $62.5 \mathrm{mM}$ GABA. $20 \mathrm{mM}$ L-glutamine and $151 \mathrm{mM}\left(\mathrm{NH}_{4}\right)_{2} \mathrm{SO}_{4}$ were included as indicated. For the WT mean values and standard deviations of three biological replicates are shown, for the mutant mean values and standard deviations of two biological replicates.

observed. This result confirms that besides GABA also GabR is essential for expression of the gabTDP genes.

\section{Influence of Plasmid-Based gabTDP Expression on the Effect of Ammonium}

The reporter gene assays had revealed that ammonium reduces transcription of gabTDP (Figure 10C) by about 35\%. To test whether this effect is sufficient to explain the growth inhibition by ammonium, we analyzed the consequences of plasmid-based overexpression of gabTDP. C. glutamicum WT was transformed with pAN6-gabTDP or pAN6 as control. The two strains were cultivated with GABA alone or with GABA plus $\left(\mathrm{NH}_{4}\right)_{2} \mathrm{SO}_{4}$ and expression of plasmid-borne gabTDP was induced with $10 \mu \mathrm{M}$ IPTG (Figure 11). With GABA alone, the WT containing pAN6gabTDP grew comparably to the control strain with pAN6, suggesting that under these conditions chromosomal gabTDP expression was not limiting growth. In medium with GABA and $\left(\mathrm{NH}_{4}\right)_{2} \mathrm{SO}_{4}$, the strain with pAN6-gabTDP grew faster than the control strain with pAN6, although still not as good as with GABA alone, even when gabTDP expression was induced with $100 \mu \mathrm{M}$ IPTG (data not shown). The results indicate that increased expression of gabTDP can partially overcome the growth inhibition by $\left(\mathrm{NH}_{4}\right)_{2} \mathrm{SO}_{4}$.

\section{DISCUSSION}

In this study, we analyzed the regulation of GABA utilization in the actinobacterial model organism C. glutamicum. The fact that C. glutamicum possesses the genes/proteins required for GABA uptake and metabolism suggests that GABA occurs in its natural soil habitat, where it could be derived e.g., from decomposed plant material or formed by other microorganisms via glutamate decarboxylation. We show that expression of the gabTDP operon encoding the proteins involved in GABA uptake and catabolism is transcriptionally activated by the divergently encoded regulator GabR. GabR is essential for growth of C. glutamicum on GABA. The observation that growth of a $\triangle g a b R$ mutant could be restored by plasmid-based, GabR-independent expression of the gabTDP genes indicated that no additional genes activated by GabR 

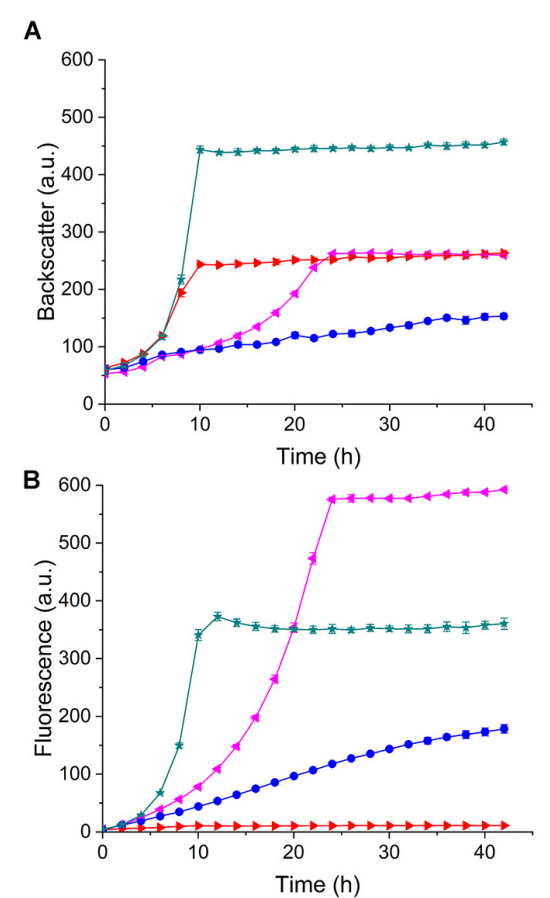
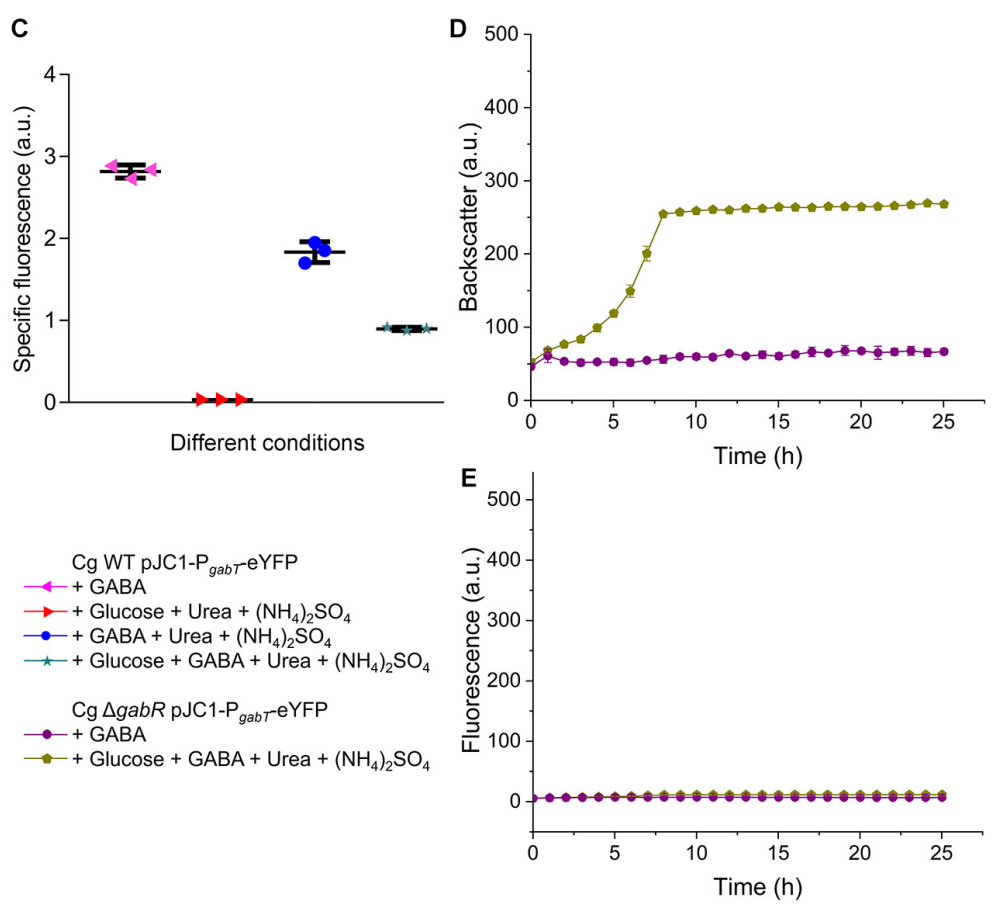

FIGURE 10 | Relevance of GabR for gabTDP transcription. C. glutamicum WT or the $\triangle$ gabR mutant transformed with the reporter plasmid pJC1-P gabT-eYFP were precultivated in BHIS medium and washed with phosphate buffer before inoculation of the main cultures. The cultivations were performed in a BioLector microcultivation system at $30^{\circ} \mathrm{C}$ and $1200 \mathrm{rpm}$ using $750 \mu \mathrm{l} \mathrm{CGXII} \mathrm{minimal} \mathrm{medium} \mathrm{supplemented} \mathrm{with} \mathrm{GABA}(62.5 \mathrm{mM}), \mathrm{glucose}(41.7 \mathrm{mM}),(\mathrm{NH})_{2} \mathrm{SO}_{4}(151 \mathrm{mM})$, and urea $(83 \mathrm{mM})$ as indicated. (A,B) Growth and eYFP fluorescence representing the activity of the gabTDP promoter of $C$. glutamicum WT with pJC1-P gabT-eYFP. (C) Specific fluorescence (ratio fluorescence/backscatter) of the cultures shown in (A) and (B) after 40 h. (D,E) Growth and fluorescence C. glutamicum $\Delta$ gabR harboring pJC1-P gabT-eYFP. Mean values and standard deviations of three biological replicates are shown.

are required for GABA utilization, characterizing GabR as a local regulator.

GabR belongs to the PucR family of transcriptional regulators (Pfam PF07905). According to Pfam, more than 95\% of the PucR sequences in the database are derived from Actinobacteria or Firmicutes. About half of the PucR family members in the database contain a GGDEF-like domain. Only few PucR-type regulators were studied to date, all of which contain the GGDEFlike domain, but a specific function of this domain has not been reported. These regulators are $B$. subtilis PucR involved in purine catabolism (Beier et al., 2002), B. subtilis PutR involved in proline utilization (Belitsky, 2011), B. subtilis AdeR involved in alanine catabolism (Lin et al., 2012), Streptomyces ambofaciens Srm22 (SrmR) controlling expression of a polyketide synthase gene for the synthesis of an antibiotic (Geistlich et al., 1992; Karray et al., 2010), and Escherichia coli CdaR (SdaR), which regulates genes involved in the uptake and metabolism of galactarate and glucarate (Monterrubio et al., 2000). All of these PucR regulators are activators, except for B. subtilis PucR, which acts both as activator and as repressor. GabR from C. glutamicum is the first characterized member of the PucR family that does not contain a GGDEF-like domain. Our results suggest that GabR binds to two 21 bp inverted repeats in the gabTDP promoter region. For AdeR, a $24 \mathrm{bp}$ inverted repeat and for PutR, a $17 \mathrm{bp}$ inverted repeat have been determined as binding sites, which is similar to our findings (Belitsky, 2011; Lin et al., 2012). The binding site of PucR is not palindromic (Beier et al., 2002) and the binding sites for Srm22 and CdaR have not been determined yet.

Gel filtration of GabR indicated that it forms octamers. As the oligomeric state of other PucR-like regulators has not been determined yet, we do not know whether this is a specific feature of this group of regulators. We searched for other octameric transcriptional regulators to compare their binding patterns and function. The LysR-type transcriptional regulator (LTTR) CrgA of Neisseria meningitides forms octameric rings and is proposed to bind to two binding sites in its target promoter with two stacked octameric rings (Sainsbury et al., 2009). The two CrgA binding sites cover a region of 63 bp, which is quite similar in size to the region covered by our two proposed motifs. CrgA also binds to DNA fragments containing just one of the binding sites (Sainsbury et al., 2009), but with strongly decreased affinity, which is also comparable to our data. GabR might work in a similar manner. Regulators belonging to the Lrp family are also frequently forming octamers, for example Lrp of E. coli (de los Rios and Perona, 2007), LrpA of Pyrococcus furiosus (Leonard et al., 2001), LrpA of Mycobacterium tuberculosis (Reddy et al., 2008; Song et al., 2016), AldR of M. tuberculosis (Dey et al., 2016), or BarR of the archeum Sulfolobus acidocaldarius (Liu et al., 2014).

Transcriptional activators for catabolic pathways often require the corresponding substrate or one of its degradation products as co-activator. In the case of GabR from C. glutamicum, binding 


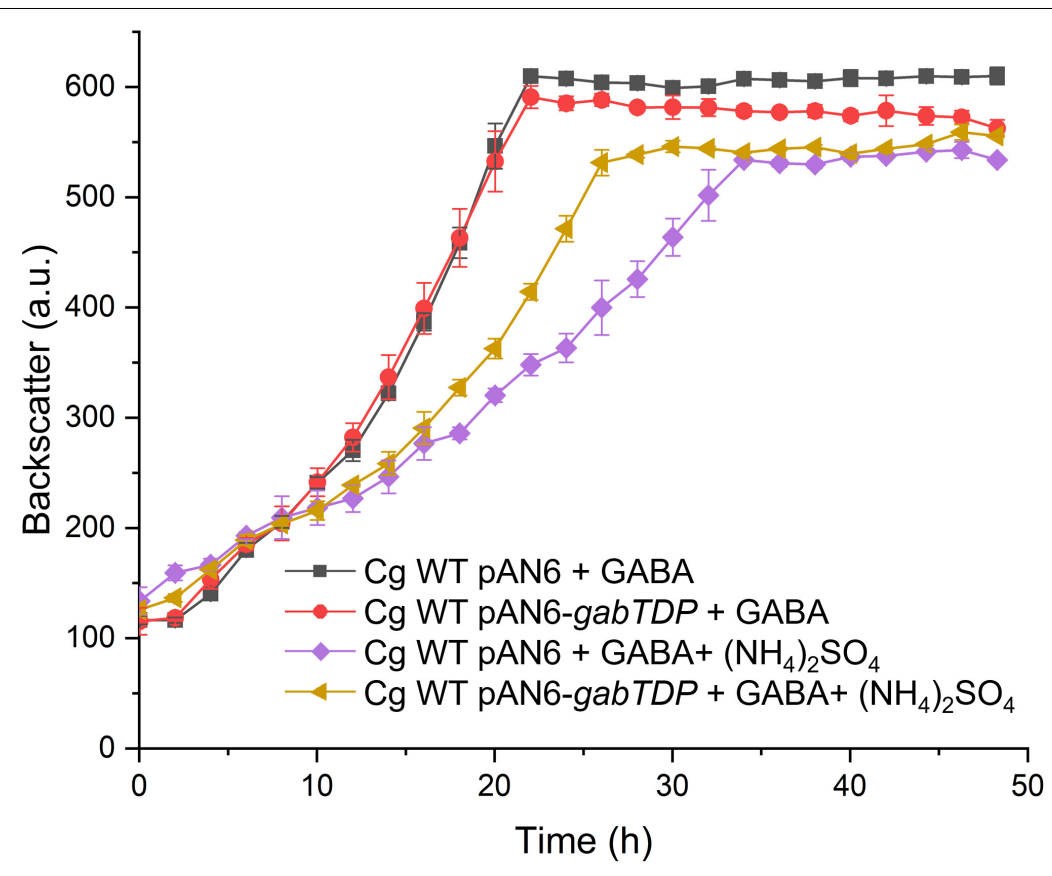

FIGURE 11 | Growth of C. glutamicum WT harboring pAN6-gabTDP or pAN6 with different substrates in the presence of $10 \mu \mathrm{M}$ IPTG. Growth experiments were performed in a BioLector microcultivation system with 48-well Flower plates containing $750 \mu \mathrm{L}$ CGXII minimal medium supplemented with GABA (62.5 mM) and $\left(\mathrm{NH}_{4}\right)_{2} \mathrm{SO}_{4}(151 \mathrm{mM})$ as indicated. BHIS medium was used for precultures and the cells were washed with phosphate buffer before inoculation of the main culture. Mean values and standard deviations of three biological replicates are shown.

to its target DNA did not require the presence of GABA and the presence of GABA had no obvious influence on the binding affinity (Supplementary Figure 9). GabR might bind to its target DNA both in the apo-state and in the ligandbound state, but requires binding of GABA or another effector metabolite to trigger a conformational change that is necessary to activate transcription of gabTDP. Such a situation was found e.g., for $B$. subtilis $\mathrm{GabR}_{\mathrm{Bs}}$, which binds to its target promoter independent of GABA, but transcription activation of the target genes requires binding of GABA and PLP (Wu et al., 2017). However, GabR Bs belongs to a different protein family than GabR of C. glutamicum and also PLP had no influence on GabR binding to DNA, neither alone nor in combination with GABA (Supplementary Figure 9). In case of $B$. subtilis PutR, the presence of proline increased the affinity for its target DNA about 10-fold (Belitsky, 2011), whereas for B. subtilis AdeR, L-alanine did not increase the affinity for the target promoter (Lin et al., 2012). Further studies are required to identify the co-activator(s) of GabR and the mechanism of transcriptional activation.

The GabR binding site is located immediately upstream of the -35 region of $\mathrm{P}_{\text {gabTDP }}$ (Figure 6), which is a typical position for transcriptional activators. However, in the transcriptome analysis, not only the gabTDP mRNA levels were increased during growth with GABA, but also the gabR mRNA level, although to a much lesser extent (4-fold) compared to gabTDP (65- to 87-fold). As the GabR binding site is located downstream of the -10 region of the $g a b R$ promoter identified in previous RNAseq studies (Pfeifer-Sancar et al., 2013), the question arises how the apparent positive autoregulation of $g a b R$ is accomplished. One possibility could be an alternative transcriptional start site, leading e.g., to a leaderless transcript, which is found quite often in C. glutamicum. Our RNAseq analysis indeed identified a possible alternative TSS located $11 \mathrm{bp}$ upstream of the gabR start codon (Figure 6A), but also in this case the promoter region overlaps with one of the two GabR binding sites.

When GABA is used as sole carbon source by C. glutamicum, growth requires the formation of PEP for gluconeogenesis. This task is fulfilled by PEP carboxykinase encoded by the pck gene (Riedel et al., 2001). Expression of the pck gene was found to be slighly upregulated in cells grown with GABA (1.68-fold, $p$-value 0.02), supporting its requirement in gluconeogenesis. Transcription of pck is subject to regulation by at least four transcriptional regulators and upregulation during growth on GABA might be due to derepression by RamA or activation by GntR1/GntR2 (Klaffl et al., 2013).

We observed that ammonium inhibits growth with GABA, with $10 \mathrm{mM}$ already showing slight growth retardation. This negative effect is caused at least in part by an influence on gabTDP transcription, which was reduced by about 35\% in the presence of $151 \mathrm{mM}$ ammonium and $83 \mathrm{mM}$ urea (Figure 10). The molecular basis for the diminished expression is not known yet. Control of nitrogen metabolism has been extensively studied in C. glutamicum and AmtR was identified as global regulator (Jakoby et al., 2000; Beckers et al., 2005; Buchinger et al., 2009). In the presence of sufficient nitrogen, AmtR represses a large set of genes involved in uptake and 
utilization of various nitrogen sources. However, the gabTDP operon or $g a b R$ were never identified as members of the AmtR regulon, arguing against AmtR as mediator of reduced gabTDP expression in the presence of ammonia. In our EMSA studies with purified GabR, ammonia did not influence binding to the gabT promoter region (Supplementary Figure 10), but this does not exclude an effect of ammonia on GabRactivated transcription initiation. For example, binding of ammonium to GabR might inhibit binding of GABA or another effector and thus transcriptional activation. Future studies are required to clarify the mechanism by which ammonium inhibits gabTDP expression.

Growth with GABA as sole carbon and nitrogen sources requires the formation of ammonium as substrate for glutamine synthetase. Oxidative deamination of glutamate by glutamate dehydrogenase might contribute to ammonium provision, although deletion of the $g d h$ gene had no effect on growth with GABA. An alternative possibility is the reaction catalyzed by aspartate ammonia-lyase, which catalyzes the conversion of aspartate to fumarate and ammonia (Dover and Halpern, 1972). The corresponding gene aspA (cg1697) was 2.50-fold upregulated in cells grown with GABA and urea compared to cells grown with glucose and urea. The observation that glutamine supplementation improved the growth rate with GABA suggests that glutamine availability in the absence of supplementation is limited, presumably by limited availability of the ammonia for glutamine synthetase. However, glutamine stimulated growth also in the presence of ammonium. In this situation, glutamine synthetase activity might be limiting due to limited expression of the $g \ln A$ gene in the presence of ammonium (Nolden et al., 2001; Strösser et al., 2004) and due to limited activity of the enzyme due to adenylylation by GlnE (Amon et al., 2010; Rehm and Burkovski, 2011). We also tested whether ammonium inhibits the activity of the GabT transaminase activity using purified GabT, but observed only a slight reduction by $6 \%$ in the presence of $30 \mathrm{mM}\left(\mathrm{NH}_{4}\right)_{2} \mathrm{SO}_{4}\left(9.07 \pm 0.33 \mu \mathrm{mol} \mathrm{min} \mathrm{mg}^{-1} \mathrm{mg}^{-1}\right.$ vs. $9.69 \pm 0.12 \mu \mathrm{mol} \mathrm{min} \mathrm{mg}^{-1}$ in the absence of ammonium sulfate).

Besides ammonium, also the presence of alternative carbon sources had a negative influence on the expression of the gabTDP operon. The inhibition by glucose, gluconate, and myoinositol is presumably caused by repression of gabTDP by the global cAMP-dependent transcriptional regulator GlxR. GlxR can function both as activator and repressor, depending on the localization of the binding site. A GlxR binding site (5' TGTATCTCACCTCACA- $3^{\prime}$ ) has been detected in the gabR-gabT intergenic region (Toyoda et al., 2011; Jungwirth et al., 2013), which is located downstream of the gabT TSS (Figure 6A), indicating a repressor function of GlxR for gabTDP. GlxRbinding to DNA is controlled by cAMP, which is formed by the membrane-bound adenylate cyclase CyaB (Cha et al., 2010; Wolf et al., 2020). The tested additional carbon sources might lead to elevated cAMP levels and thus to enhanced binding of GlxR to the gabT promoter and repression. In contrast to e.g., E. coli, C. glutamicum usually shows parallel consumption of carbon sources rather than diauxic growth.
This has been demonstrated e.g., for glucose and acetate (Wendisch et al., 2000), glucose and gluconate (Frunzke et al., 2008), or glucose and citrate (Brocker et al., 2009). GlxR is presumably involved in coordinating the consumption of carbon sources in C. glutamicum to avoid an overload of the metabolic capacity of the cells. In the case of GABA, a similar situation can be envisaged, where the presence of an alternative carbon source causes a reduction of the GABA utilization rate to avoid an overload of the TCA cycle at the stage of succinate.

In summary, we characterized GabR as the first PucR-type transcriptional regulator without a GGDEF-like domain and showed that GabR is essential for activating expression of the GABA catabolic genes gabTDP. Although GABA did not influence the binding affinity of purified GabR to its target promoter, we assume it to be the most likely effector molecule, as the $g a b T D P$ genes were not expressed in the absence of GABA. The inhibitory effect of ammonium on GABA utilization is caused via inhibition of gabTDP transcription via a yet unknown mechanism and presumably via a negative effect on glutamine synthetase expression and activity. The negative effect on gabTDP transcription by alternative carbon sources is likely caused by the global cAMP-dependent regulator GlxR. Many of the results obtained here will probably also be relevant for other Actinobacteria capable of utilizing GABA as carbon and nitrogen source.

\section{ORCID}

\author{
Lingfeng Zhu \\ orcid.org/0000-0002-9145-5419 \\ Christina Mack \\ orcid.org/0000-0002-3495-3796 \\ Astrid Wirtz \\ orcid.org/0000-0003-2159-3717 \\ Angela Kranz \\ orcid.org/0000-0002-8000-0400 \\ Tino Polen \\ orcid.org/0000-0002-0065-3007 \\ Meike Baumgart \\ orcid.org/0000-0002-9874-1151 \\ Michael Bott \\ orcid.org/0000-0002-4701-8254
}

\section{DATA AVAILABILITY STATEMENT}

The microarray datasets generated for this study can be found in the NCBI Gene Expression Omnibus under the GEO accession number GSE138829. The RNAseq data are available in the GEO database with the accession number GSE156688.

\section{AUTHOR CONTRIBUTIONS}

LZ performed the majority of the experimental work presented in this study, wrote the first draft of the manuscript and 
provided most of the figures and tables. CM performed several growth experiments in shake flasks and the BioLector microcultivation system and she was responsible for the RNA isolation for RNAseq analysis. AW established and performed the HPLC method for measuring the GABA concentration in supernatants. AK evaluated the RNAseq data and TP supported the DNA microarray analysis. $\mathrm{MBa}$ and $\mathrm{MBo}$ designed the study, supervised the experimental work, and evaluated the data together with LZ, AK, and TP. MBa prepared figures added during revision. $\mathrm{MBa}$ and $\mathrm{MBo}$ revised the manuscript and $\mathrm{MBO}$ was responsible for the final version. All authors contributed to the article and approved the submitted version.

\section{FUNDING}

LZ was supported by a Ph.D. fellowship of the China Scholarship Council. Parts of this publication are derived from the Ph.D. thesis of LZ (Zhu, 2020).

\section{REFERENCES}

Abdou, A. M., Higashiguchi, S., Horie, K., Kim, M., Hatta, H., and Yokogoshi, H. (2006). Relaxation and immunity enhancement effects of $\gamma$-aminobutyric acid (GABA) administration in humans. BioFactors 26, 201-208. doi: 10.1002/biof. 5520260305

Amon, J., Titgemeyer, F., and Burkovski, A. (2010). Common patterns - unique features: nitrogen metabolism and regulation in Gram-positive bacteria. FEMS Microbiol. Rev. 34, 588-605. doi: 10.1111/j.1574-6976.2010.00216.x

Bailey, T. L., Williams, N., Misleh, C., and Li, W. W. (2006). MEME: discovering and analyzing DNA and protein sequence motifs. Nucleic Acids Res. 34, W369W373. doi: 10.1093/nar/gkl198

Baumgart, M., Luder, K., Grover, S., Gätgens, C., Besra, G. S., and Frunzke, J. (2013). IpsA, a novel LacI-type regulator, is required for inositol-derived lipid formation in Corynebacteria and Mycobacteria. BMC Biol. 11:122. doi: 10.1186/ 1741-7007-11-122

Beckers, G., Strösser, J., Hildebrandt, U., Kalinowski, J., Farwick, M., Krämer, R., et al. (2005). Regulation of AmtR-controlled gene expression in Corynebacterium glutamicum: mechanism and characterization of the AmtR regulon. Mol. Microbiol. 58, 580-595.

Beier, L., Nygaard, P., Jarmer, H., and Saxild, H. H. (2002). Transcription analysis of the Bacillus subtilis PucR regulon and identification of a cis-acting sequence required for PucR-regulated expression of genes involved in purine catabolism. J. Bacteriol. 184, 3232-3241. doi: 10.1128/jb.184.12.3232-3241.2002

Belitsky, B. R. (2004). Bacillus subtilis GabR, a protein with DNA-binding and aminotransferase domains, is a PLP-dependent transcriptional regulator. J. Mol. Biol. 340, 655-664. doi: 10.1016/j.jmb.2004.05.020

Belitsky, B. R. (2011). Indirect repression by Bacillus subtilis CodY via displacement of the activator of the proline utilization operon. J. Mol. Biol. 413, 321-336. doi: 10.1016/j.jmb.2011.08.003

Ben-Ari, Y., Gaiarsa, J. L., Tyzio, R., and Khazipov, R. (2007). GABA: a pioneer transmitter that excites immature neurons and generates primitive oscillations. Physiol. Rev. 87, 1215-1284. doi: 10.1152/physrev.00017.2006

Bertani, G. (1951). Studies on lysogenesis. I. The mode of phage liberation by lysogenic Escherichia coli. J. Bacteriol. 62, 293-300.

Brocker, M., Schaffer, S., Mack, C., and Bott, M. (2009). Citrate utilization by Corynebacterium glutamicum is controlled by the CitAB two-component system through positive regulation of the citrate transport genes citH and tctCBA. J. Bacteriol. 191, 3869-3880. doi: 10.1128/jb.00113-09

Buchinger, S., Strösser, J., Rehm, N., Hänssler, E., Hans, S., Bathe, B., et al. (2009). A combination of metabolome and transcriptome analyses reveals new targets of the Corynebacterium glutamicum nitrogen regulator AmtR. J. Biotechnol. 140, $68-74$.

\section{ACKNOWLEDGMENTS}

The authors are most grateful to Andreas Burkovski (Erlangen, Germany) for providing the C. glutamicum strains LN $\Delta \mathrm{GDH}$ (C. glutamicum $\Delta g d h)$, LN $\Delta \mathrm{GS}$ (C. glutamicum $\Delta g \ln A), \mathrm{LN} \triangle g$ ltBD (C. glutamicum $\triangle g l t B D$ ) and ATCC 13032 DA-2 (C. glutamicum $\Delta g \ln A \Delta g \ln A 2 \Delta g d h)$ and information on nitrogen metabolism in $C$. glutamicum. In addition we thank Karen Wohlers for the help with glucose determination via HPLC and Jan Marienhagen for providing plasmid pJM0462.

\section{SUPPLEMENTARY MATERIAL}

The Supplementary Material for this article can be found online at: https://www.frontiersin.org/articles/10.3389/fmicb. 2020.544045/full\#supplementary-material

Bussmann, M., Baumgart, M., and Bott, M. (2010). RosR (Cg1324), a hydrogen peroxide-sensitive MarR-type transcriptional regulator of Corynebacterium glutamicum. J. Biol. Chem. 285, 29305-29318. doi: 10.1074/jbc.M110. 156372

Cha, P. H., Park, S. Y., Moon, M. W., Subhadra, B., Oh, T. K., Kim, E., et al. (2010). Characterization of an adenylate cyclase gene (cyaB) deletion mutant of Corynebacterium glutamicum ATCC 13032. Appl. Microbiol. Biotechnol. 85, 1061-1068.

Cotter, P. D., and Hill, C. (2003). Surviving the acid test: responses of gram-positive bacteria to low pH. Microbiol. Mol. Biol. Rev. 67, 429-453. doi: 10.1128/Mmbr. 37.3.429-453.2003

De Biase, D., and Pennacchietti, E. (2012). Glutamate decarboxylase-dependent acid resistance in orally acquired bacteria: function, distribution and biomedical implications of the gadBC operon. Mol. Microbiol. 86, 770-786. doi: 10.1111/ mmi.12020

de los Rios, S., and Perona, J. J. (2007). Structure of the Escherichia coli leucineresponsive regulatory protein Lrp reveals a novel octameric assembly. J. Mol. Biol. 366, 1589-1602. doi: 10.1016/j.jmb.2006.12.032

Dey, A., Shree, S., Pandey, S. K., Tripathi, R. P., and Ramachandran, R. (2016). Crystal structure of Mycobacterium tuberculosis H37Rv AldR (Rv2779c), a regulator of the ald gene: DNA binding and identification of small molecule inhibitors. J. Biol. Chem. 291, 11967-11980. doi: 10.1074/jbc.M115.700484

Dhakal, R., Bajpai, V. K., and Baek, K. H. (2012). Production of GABA ( $\gamma$-aminobutyric acid) by microorganisms: a review. Braz. J. Microbiol. 43, 1230-1241. doi: 10.1590/S1517-83822012000400001

Dover, S., and Halpern, Y. S. (1972). Utilization of $\gamma$-aminobutyric acid as the sole carbon and nitrogen source by Escherichia coli K-12 mutants. J. Bacteriol. 109, $835-843$.

Edayathumangalam, R., Wu, R., Garcia, R., Wang, Y., Wang, W., Kreinbring, C. A., et al. (2013). Crystal structure of Bacillus subtilis GabR, an autorepressor and transcriptional activator of gabT. Proc. Natl. Acad. Sci. U.S.A. 110, 17820-17825. doi: $10.1073 /$ pnas. 1315887110

Eggeling, L., and Bott, M. (eds) (2005). Handbook of Corynebacterium glutamicum. Boca Raton, FL: CRC Press.

Ewing, B., and Green, P. (1998). Base-calling of automated sequencer traces using phred. II. Error probabilities. Genome Res. 8, 186-194.

Feehily, C., and Karatzas, K. A. (2013). Role of glutamate metabolism in bacterial responses towards acid and other stresses. J. Appl. Microbiol. 114, 11-24. doi: 10.1111/j.1365-2672.2012.05434.x

Foster, J. W. (2004). Escherichia coli acid resistance: tales of an amateur acidophile. Nat. Rev. Microbiol. 2, 898-907. doi: 10.1038/nrmicro1021

Frunzke, J., Engels, V., Hasenbein, S., Gätgens, C., and Bott, M. (2008). Co-ordinated regulation of gluconate catabolism and glucose uptake in 
Corynebacterium glutamicum by two functionally equivalent transcriptional regulators, GntR1 and GntR2. Mol. Microbiol. 67, 305-322.

Geistlich, M., Losick, R., Turner, J. R., and Rao, R. N. (1992). Characterization of a novel regulatory gene governing the expression of a polyketide synthase gene in Streptomyces ambofaciens. Mol. Microbiol. 6, 2019-2029. doi: 10.1111/j.13652958.1992.tb01374.x

Gibson, D. G., Young, L., Chuang, R. Y., Venter, J. C., Hutchison, C. A., and Smith, H. O. (2009). Enzymatic assembly of DNA molecules up to several hundred kilobases. Nat. Meth. 6, 343-345. doi: 10.1038/Nmeth.1318

Hanahan, D. (1983). Studies on transformation of Escherichia coli with plasmids. J. Mol. Biol. 166, 557-580.

Hilker, R., Stadermann, K. B., Doppmeier, D., Kalinowski, J., Stoye, J., Straube, J., et al. (2014). ReadXplorer-visualization and analysis of mapped sequences. Bioinformatics 30, 2247-2254. doi: 10.1093/bioinformatics/btu205

Hong, J., and Kim, K. J. (2019). Crystal structure of $\gamma$-aminobutyrate aminotransferase in complex with a PLP-GABA adduct from Corynebacterium glutamicum. Biochem. Biophys. Res. Commun. 514, 601-606. doi: 10.1016/j.bbrc. 2019.04.194

Jakoby, M., Nolden, L., Meier-Wagner, J., Krämer, R., and Burkovski, A. (2000). AmtR, a global repressor in the nitrogen regulation system of Corynebacterium glutamicum. Mol. Microbiol. 37, 964-977.

Jakoby, M., Tesch, M., Sahm, H., Krämer, R., and Burkovski, A. (1997). Isolation of the Corynebacterium glutamicum glnA gene encoding glutamine synthetase I. FEMS Microbiol. Lett. 154, 81-88.

Jorge, J. M., Leggewie, C., and Wendisch, V. F. (2016). A new metabolic route for the production of gamma-aminobutyric acid by Corynebacterium glutamicum from glucose. Amino Acids 48, 2519-2531. doi: 10.1007/s00726-016-2272-6

Jungwirth, B., Sala, C., Kohl, T. A., Uplekar, S., Baumbach, J., Cole, S. T., et al. (2013). High-resolution detection of DNA binding sites of the global transcriptional regulator GlxR in Corynebacterium glutamicum. Microbiology 159, 12-22. doi: 10.1099/mic.0.062059-0

Kabus, A., Niebisch, A., and Bott, M. (2007). Role of cytochrome $b d$ oxidase from Corynebacterium glutamicum in growth and lysine production. Appl. Environ. Microbiol. 73, 861-868.

Kalinowski, J., Bathe, B., Bartels, D., Bischoff, N., Bott, M., Burkovski, A., et al. (2003). The complete Corynebacterium glutamicum ATCC 13032 genome sequence and its impact on the production of L-aspartate-derived amino acids and vitamins. J. Biotechnol. 104, 5-25.

Kapust, R. B., and Waugh, D. S. (1999). Escherichia coli maltose-binding protein is uncommonly effective at promoting the solubility of polypeptides to which it is fused. Protein Sci. 8, 1668-1674. doi: 10.1110/ps.8.8.1668

Karray, F., Darbon, E., Nguyen, H. C., Gagnat, J., and Pernodet, J. L. (2010). Regulation of the biosynthesis of the macrolide antibiotic spiramycin in Streptomyces ambofaciens. J. Bacteriol. 192, 5813-5821. doi: 10.1128/JB. 00712-10

Kawasaki, N., Nakayama, A., Yamano, N., Takeda, S., Kawata, Y., Yamamoto, N., et al. (2005). Synthesis, thermal and mechanical properties and biodegradation of branched polyamide 4. Polymer 46, 9987-9993. doi: 10.1016/j.polymer.2005. 06.092

Keilhauer, C., Eggeling, L., and Sahm, H. (1993). Isoleucine synthesis in Corynebacterium glutamicum: molecular analysis of the $i l v B-i l v N-i l v C$ operon. J. Bacteriol. 175, 5595-5603.

Kensy, F., Engelbrecht, C., and Büchs, J. (2009a). Scale-up from microtiter plate to laboratory fermenter: evaluation by online monitoring techniques of growth and protein expression in Escherichia coli and Hansenula polymorpha fermentations. Microb. Cell Fact. 8:68. doi: 10.1186/14752859-8-68

Kensy, F., Zang, E., Faulhammer, C., Tan, R. K., and Büchs, J. (2009b). Validation of a high-throughput fermentation system based on online monitoring of biomass and fluorescence in continuously shaken microtiter plates. Microb. Cell Fact. 8:31. doi: $10.1186 / 1475-2859-8-31$

Kinoshita, S., Udaka, S., and Shimono, M. (1957). Studies on amino acid fermentation. Part I. Production of L-glutamic acid by various microorganisms. J. Gen. Appl. Microbiol. 3, 193-205.

Klaffl, S., Brocker, M., Kalinowski, J., Eikmanns, B. J., and Bott, M. (2013). Complex regulation of the phosphoenolpyruvate carboxykinase gene pck and characterization of its GntR-Type regulator IolR as a repressor of myo-inositol utilization genes in Corynebacterium glutamicum. J. Bacteriol. 195, 4283-4296. doi: 10.1128/JB.00265-13
Kortmann, M., Kuhl, V., Klaffl, S., and Bott, M. (2015). A chromosomally encoded T7 RNA polymerase-dependent gene expression system for Corynebacterium glutamicum: construction and comparative evaluation at the single-cell level. Microb. Biotechnol. 8, 253-265. doi: 10.1111/1751-7915.12236

Krulwich, T. A., Sachs, G., and Padan, E. (2011). Molecular aspects of bacterial pH sensing and homeostasis. Nat. Rev. Microbiol. 9, 330-343. doi: 10.1038/ nrmicro2549

Kurihara, S., Kato, K., Asada, K., Kumagai, H., and Suzuki, H. (2010). A putrescineinducible pathway comprising PuuE-YneI in which $\gamma$-aminobutyrate is degraded into succinate in Escherichia coli K-12. J. Bacteriol. 192, 4582-4591. doi: 10.1128/JB.00308-10

Leonard, P. M., Smits, S. H., Sedelnikova, S. E., Brinkman, A. B., de Vos, W. M., van der Oost, J., et al. (2001). Crystal structure of the Lrp-like transcriptional regulator from the archaeon Pyrococcus furiosus. EMBO J. 20, 990-997. doi: 10.1093/emboj/20.5.990

Lin, T. H., Wei, G. T., Su, C. C., and Shaw, G. C. (2012). AdeR, a PucR-type transcription factor, activates expression of L-alanine dehydrogenase and is required for sporulation of Bacillus subtilis. J. Bacteriol. 194, 4995-5001. doi: 10.1128/JB.00778- 12

Lindroth, P., and Mopper, K. (1979). High-performance liquid chromatographic determination of subpicomole amounts of amino acids by precolumn fluorescence derivatization with o-phthaldialdehyde. Anal. Chem. 51, 1667-1674.

Liu, H., Orell, A., Maes, D., van Wolferen, M., Lindas, A. C., Bernander, R., et al. (2014). BarR, an Lrp-type transcription factor in Sulfolobus acidocaldarius, regulates an aminotransferase gene in a $\beta$-alanine responsive manner. Mol. Microbiol. 92, 625-639. doi: 10.1111/mmi.12583

Marienhagen, J., Kennerknecht, N., Sahm, H., and Eggeling, L. (2005). Functional analysis of all aminotransferase proteins inferred from the genome sequence of Corynebacterium glutamicum. J. Bacteriol. 187, 7639-7646.

Medema, M. H., Takano, E., and Breitling, R. (2013). Detecting sequence homology at the gene cluster level with MultiGeneBlast. Mol. Biol. Evol. 30, 1218-1223. doi: $10.1093 / \mathrm{molbev} / \mathrm{mst} 025$

Michaeli, S., and Fromm, H. (2015). Closing the loop on the GABA shunt in plants: are GABA metabolism and signaling entwined? Front. Plant Sci. 6:419. doi: $10.3389 /$ fpls.2015.00419

Monterrubio, R., Baldoma, L., Obradors, N., Aguilar, J., and Badia, J. (2000). A common regulator for the operons encoding the enzymes involved in $\mathrm{D}$-galactarate, D-glucarate, and D-glycerate utilization in Escherichia coli. J. Bacteriol. 182, 2672-2764. doi: 10.1128/jb.182.9.2672-2674.2000

Müller, T., Strösser, J., Buchinger, S., Nolden, L., Wirtz, A., Krämer, R., et al. (2006). Mutation-induced metabolite pool alterations in Corynebacterium glutamicum: towards the identification of nitrogen control signals. J. Biotechnol. 126, 440453. doi: 10.1016/j.jbiotec.2006.05.015

Ni, Y., Shi, F., and Wang, N. (2015). Specific $\gamma$-aminobutyric acid decomposition by gabP and gabT under neutral $\mathrm{pH}$ in recombinant Corynebacterium glutamicum. Biotechnol. Lett. 37, 2219-2227. doi: 10.1007/s10529-015-1897-y

Niebisch, A., and Bott, M. (2001). Molecular analysis of the cytochrome $b c_{1}-a a_{3}$ branch of the Corynebacterium glutamicum respiratory chain containing an unusual diheme cytochrome $c_{1}$. Arch. Microbiol. 175, 282-294.

Nolden, L., Farwick, M., Krämer, R., and Burkovski, A. (2001). Glutamine synthetases of Corynebacterium glutamicum: transcriptional control and regulation of activity. FEMS Microbiol. Lett. 201, 91-98.

Peng, Q., Yang, M., Wang, W., Han, L., Wang, G., Wang, P., et al. (2014). Activation of gab cluster transcription in Bacillus thuringiensis by $\gamma$-aminobutyric acid or succinic semialdehyde is mediated by the sigma-54-dependent transcriptional activator GabR. BMC Microbiol. 14:306. doi: 10.1186/s12866-014-0306-3

Pennacchietti, E., D’Alonzo, C., Freddi, L., Occhialini, A., and De Biase, D. (2018). The glutaminase-dependent acid resistance system: qualitative and quantitative assays and analysis of its distribution in enteric bacteria. Front. Microbiol. 9:2869. doi: $10.3389 /$ fmicb. 2018.02869

Pfeifer-Sancar, K., Mentz, A., Rückert, C., and Kalinowski, J. (2013). Comprehensive analysis of the Corynebacterium glutamicum transcriptome using an improved RNAseq technique. BMC Genomics 14:888. doi: $10.1186 / 1471-2164-14-888$

Reddy, M. C., Gokulan, K., Jacobs, W. R. Jr., Ioerger, T. R., and Sacchettini, J. C. (2008). Crystal structure of Mycobacterium tuberculosis LrpA, a leucine-responsive global regulator associated with starvation response. Protein Sci. 17, 159-170. doi: 10.1110/ps.073192208 
Rehm, N., and Burkovski, A. (2011). Engineering of nitrogen metabolism and its regulation in Corynebacterium glutamicum: influence on amino acid pools and production. Appl. Microbiol. Biotechnol. 89, 239-248. doi: 10.1007/s00253-0102922-7

Rehm, N., Georgi, T., Hiery, E., Degner, U., Schmiedl, A., Burkovski, A., et al. (2010). L-Glutamine as a nitrogen source for Corynebacterium glutamicum: derepression of the AmtR regulon and implications for nitrogen sensing. Microbiology 156, 3180-3193. doi: 10.1099/Mic.0.040667-0

Richhardt, J., Bringer, S., and Bott, M. (2012). Mutational analysis of the pentose phosphate and Entner-Doudoroff pathways in Gluconobacter oxydans reveals improved growth of a $\Delta e d d \Delta e d a$ mutant on mannitol. Appl. Environ. Microbiol. 78, 6975-6986. doi: 10.1128/AEM.01166-12

Riedel, C., Rittmann, D., Dangel, P., Möckel, B., Petersen, S., Sahm, H., et al. (2001). Characterization of the phosphoenolpyruvate carboxykinase gene from Corynebacterium glutamicum and significance of the enzyme for growth and amino acid production. J. Mol. Microbiol. Biotechnol. 3, 573-583.

Sainsbury, S., Lane, L. A., Ren, J., Gilbert, R. J., Saunders, N. J., Robinson, C. V., et al. (2009). The structure of CrgA from Neisseria meningitidis reveals a new octameric assembly state for LysR transcriptional regulators. Nucleic Acids Res. 37, 4545-4558. doi: 10.1093/nar/gkp445

Sambrook, J., Fritsch, E. F., and Maniatis, T. (1989). Molecular Cloning. A Laboratory Manual. Cold Spring Harbor, NY: Cold Spring Harbor Laboratory Press.

Schäfer, A., Tauch, A., Jäger, W., Kalinowski, J., Thierbach, G., and Pühler, A. (1994). Small mobilizable multipurpose cloning vectors derived from the Escherichia coli plasmids pK18 and pK19 - Selection of defined deletions in the chromosome of Corynebacterium glutamicum. Gene 145, 69-73.

Schneider, B. L., and Reitzer, L. (2012). Pathway and enzyme redundancy in putrescine catabolism in Escherichia coli. J. Bacteriol. 194, 4080-4088. doi: 10.1128/JB.05063-11

Schneider, B. L., Ruback, S., Kiupakis, A. K., Kasbarian, H., Pybus, C., and Reitzer, L. (2002). The Escherichia coli gabDTPC operon: specific $\gamma$-aminobutyrate catabolism and nonspecific induction. J. Bacteriol. 184, 6976-6986. doi: 10. 1128/jb.184.24.6976-6986.2002

Schultz, A. C., Nygaard, P., and Saxild, H. H. (2001). Functional analysis of 14 genes that constitute the purine catabolic pathway in Bacillus subtilis and evidence for a novel regulon controlled by the PucR transcription activator. J. Bacteriol. 183, 3293-3302. doi: 10.1128/JB.183.11.3293-3302.2001

Scott, E. M., and Jakoby, W. B. (1958). Pyrrolidine metabolism - soluble $\gamma$-aminobutyric transaminase and semialdehyde dehydrogenase. Science 128, 361-362. doi: 10.1126/science.128.3320.361-a

Shi, F., Jiang, J., Li, Y., Li, Y., and Xie, Y. (2013). Enhancement of $\gamma$-aminobutyric acid production in recombinant Corynebacterium glutamicum by co-expressing two glutamate decarboxylase genes from Lactobacillus brevis. J. Ind. Microbiol. Biotechnol. 40, 1285-1296. doi: 10.1007/s10295-013-1316-0

Shi, F., and Li, Y. (2011). Synthesis of $\gamma$-aminobutyric acid by expressing Lactobacillus brevis-derived glutamate decarboxylase in the Corynebacterium glutamicum strain ATCC 13032. Biotechnol. Lett. 33, 2469-2474. doi: 10.1007/ s10529-011-0723-4

Shi, F., Si, H., Ni, Y. L., Zhang, L., and Li, Y. F. (2017). Transaminase encoded by NCgl2515 gene of Corynebacterium glutamicum ATCC 13032 is involved in $\gamma$-aminobutyric acid decomposition. Process Biochem. 55, 55-60. doi: 10.1016/ j.procbio.2017.01.016

Shiio, I., and Ozaki, H. (1970). Regulation of nicotinamide adenine dinucleotide phosphate-specific glutamate dehydrogenase from Brevibacterium flavum, a glutamate-producing bacterium. J. Biochem. 68, 633-647.

Siewe, R. M., Weil, B., Burkovski, A., Eggeling, L., Krämer, R., and Jahns, T. (1998). Urea uptake and urease activity in Corynebacterium glutamicum. Arch. Microbiol. 169, 411-416.

Song, N., Cui, Y., Li, Z., Chen, L., and Liu, S. (2016). New targets and cofactors for the transcription factor LrpA from Mycobacterium tuberculosis. DNA Cell Biol 35, 167-176. doi: 10.1089/dna.2015.3040

Strandwitz, P., Kim, K. H., Terekhova, D., Liu, J. K., Sharma, A., Levering, J., et al. (2019). GABA-modulating bacteria of the human gut microbiota. Nat. Microbiol. 4:396.

Strösser, J., Lüdke, A., Schaffer, S., Krämer, R., and Burkovski, A. (2004). Regulation of GlnK activity: modification, membrane sequestration and proteolysis as regulatory principles in the network of nitrogen control in Corynebacterium glutamicum. Mol. Microbiol. 54, 132-147.
Studier, F. W., and Moffatt, B. A. (1986). Use of bacteriophage T7 RNA polymerase to direct selective high-level expression of cloned genes. J. Mol. Biol. 189, 113-130.

Takahashi, C., Shirakawa, J., Tsuchidate, T., Okai, N., Hatada, K., Nakayama, H., et al. (2012). Robust production of gamma-amino butyric acid using recombinant Corynebacterium glutamicum expressing glutamate decarboxylase from Escherichia coli. Enzyme Microb. Technol. 51, 171-176. doi: 10.1016/j. enzmictec.2012.05.010

Toyoda, K., Teramoto, H., Inui, M., and Yukawa, H. (2011). Genome-wide identification of in vivo binding sites of GlxR, a cyclic AMP receptor proteintype regulator in Corynebacterium glutamicum. J. Bacteriol. 193, 4123-4133. doi: 10.1128/JB.00384-11

van der Rest, M. E., Lange, C., and Molenaar, D. (1999). A heat shock following electroporation induces highly efficient transformation of Corynebacterium glutamicum with xenogeneic plasmid DNA. Appl. Microbiol. Biotechnol. 52, 541-545.

Vogt, M., Haas, S., Klaffl, S., Polen, T., Eggeling, L., van Ooyen, J., et al. (2014). Pushing product formation to its limit: metabolic engineering of Corynebacterium glutamicum for L-leucine overproduction. Metab. Eng. 22, 40-52. doi: 10.1016/j.ymben.2013.12.001

Walter, B., Kuspert, M., Ansorge, D., Krämer, R., and Burkovski, A. (2008). Dissection of ammonium uptake systems in Corynebacterium glutamicum: mechanism of action and energetics of AmtA and AmtB. J. Bacteriol. 190, 2611-2614.

Wendisch, V. F., De Graaf, A. A., Sahm, H., and Eikmanns, B. J. (2000). Quantitative determination of metabolic fluxes during coutilization of two carbon sources: comparative analyses with Corynebacterium glutamicum during growth on acetate and/or glucose. J. Bacteriol. 182, 3088-3096.

Wennerhold, J., and Bott, M. (2006). The DtxR regulon of Corynebacterium glutamicum. J. Bacteriol. 188, 2907-2918.

Wennerhold, J., Krug, A., and Bott, M. (2005). The AraC-type regulator RipA represses aconitase and other iron proteins from Corynebacterium under iron limitation and is itself repressed by DtxR. J. Biol. Chem. 280, 40500-40508.

Wolf, N., Bussmann, M., Koch-Koerfges, A., Katcharava, N., Schulte, J., Polen, T., et al. (2020). Molecular basis of growth inhibition by acetate of an adenylate cyclase-deficient mutant of Corynebacterium glutamicum. Front. Microbiol. 11:87. doi: $10.3389 /$ fmicb. 2020.00087

Wu, R., Sanishvili, R., Belitsky, B. R., Juncosa, J. I., Le, H. V., Lehrer, H. J., et al. (2017). PLP and GABA trigger GabR-mediated transcription regulation in Bacillus subtilis via external aldimine formation. Proc. Natl. Acad. Sci. U.S.A. 114, 3891-3896. doi: 10.1073/pnas.1703019114

$\mathrm{Xu}, \mathrm{N}$., Wei, L., and Liu, J. (2017). Biotechnological advances and perspectives of $\gamma$-aminobutyric acid production. World J. Microbiol. Biotechnol. 33:64. doi: 10.1007/s11274-017-2234-5

Zhao, Z., Ding, J. Y., Ma, W. H., Zhou, N. Y., and Liu, S. J. (2012). Identification and characterization of $\gamma$-aminobutyric acid uptake system $\mathrm{GabP}_{\mathrm{Cg}}(\mathrm{NCgl0464)}$ in Corynebacterium glutamicum. Appl. Environ. Microbiol. 78, 2596-2601. doi: 10.1128/AEM.07406-11

Zhu, L. (2020). $\gamma$-Aminobutyrate as Carbon and Nitrogen Source for Corynebacterium glutamicum and Regulation of the Catabolic Genes by GabR. Doctoral thesis, University of Düsseldorf, Düsseldorf.

Zhu, L., Peng, Q., Song, F., Jiang, Y., Sun, C., Zhang, J., et al. (2010). Structure and regulation of the gab gene cluster, involved in the $\gamma$-aminobutyric acid shunt, are controlled by a $\sigma^{54}$ factor in Bacillus thuringiensis. J. Bacteriol. 192, 346-355. doi: 10.1128/JB.01038-09

Conflict of Interest: The authors declare that the research was conducted in the absence of any commercial or financial relationships that could be construed as a potential conflict of interest.

Copyright (c) 2020 Zhu, Mack, Wirtz, Kranz, Polen, Baumgart and Bott. This is an open-access article distributed under the terms of the Creative Commons Attribution License (CC BY). The use, distribution or reproduction in other forums is permitted, provided the original author(s) and the copyright owner(s) are credited and that the original publication in this journal is cited, in accordance with accepted academic practice. No use, distribution or reproduction is permitted which does not comply with these terms. 